\title{
Memórias e representações da inspeção escolar nos álbuns de fotografia de Luiz Damasco Penna (São Paulo, 1928-1959)
}

Memories and representations of school inspection in the photo albums of Luiz Damasco Penna (São Paulo, 1928-1959)

Memorias y representaciones de la inspección escolar en los álbumes de fotografía de Luiz Damasco Penna (São Paulo, 1928-1959)

\author{
Rosa Fátima de Souza Chaloba \\ Universidade Estadual Paulista (Brasil) \\ Bolsista de Produtividade em Pesquisa do CNPq \\ https://orcid.org/0000-0002-3905-7317 \\ http://lattes.cnpq.br/6453276942134992 \\ rosa.souza@.unesp.br
}

Maria Apparecida Franco Pereira

Universidade Católica de Santos (Brasil)

https://orcid.org/0000-0002-7591-5171

http://lattes.cnpq.br/1870166959217314

cidaunisantos@gmail.com

\section{Resumo}

O artigo analisa memórias e representações da inspeção escolar no estado de São Paulo com base em fotografias. O estudo incide sobre uma série de 566 imagens relacionadas à atuação profissional de Luiz Damasco Penna, abrangendo o período de 1928 a 1959 insertadas em 7 álbuns de fotografias de família. A primeira parte do texto trata do sistema de inspeção escolar no Estado de São Paulo assinalando as atribuições de inspetores e delegados de ensino com vistas a delinear o campo de trabalho desses agentes da inspeção escolar. Em seguida, é apresentada a trajetória profissional do professor Luiz Damasco Penna. A segunda parte do texto põe em discussão memórias e representações do serviço de inspeção escolar em imagens fotográficas, considerando três dimensões do exercício da atividade inspetora: a) Viagens de visita às escolas; b) Acompanhamento da rede escolar; c) Participação em eventos e solenidades.

Palavras-chave: fotografias escolares; inspeção escolar; cultura escolar. 


\begin{abstract}
This paper examines memories and representations of school inspection in the state of São Paulo through photographs. The study focuses on a series of 566 images related to the professional activities of Luiz Damasco Penna, covering the period from 1928 to 1959, inserted in seven family photo albums. The first part of the paper addresses the school inspection system in the state of São Paulo, establishing the attributions of school inspectors and commissioners in order to outline the field of work of these agents of school inspection. Then, it presents the professional career of Professor Luiz Damasco Penna. The second half of the text calls into question the memories and representations of the school inspection service in photographic images considering three dimensions of the exercise of inspection activities: a) Traveling to visit schools; b) Monitoring the school network; c) Taking part in ceremonies and special events.
\end{abstract}

Keywords: school photographs; school inspection; school culture.

\title{
Resumen
}

El artículo analiza memorias y representaciones de la inspección escolar en el estado de São Paulo con base en fotografías. El estudio se refiere a una serie de 566 imágenes relacionadas con la actuación profesional de Luiz Damasco Penna que abarca el período de 1928 a 1959 insertadas en 7 álbumes de fotografías de familia. La primera parte del texto trata del sistema de inspección escolar en el estado de São Paulo señalando las atribuciones de inspectores y delegados de enseñanza con vistas a delinear el campo de trabajo de esos agentes de la inspección escolar. Después, se presenta la trayectoria profesional del profesor Luiz Damasco Penna. La segunda parte del texto pone en discusión memorias y representaciones del servicio de inspección escolar en fotos considerando tres dimensiones del ejercicio de la actividad de inspección: a) Viajes de visita a las escuelas; b) Acompañamiento de la red escolar; c) Participación en eventos y solemnidades.

Palabras clave: Fotografías escolares. Inspección escolar. Cultura escolar. 


\section{Introdução}

Luiz Damasco Penna teve uma importante atuação no serviço de inspeção escolar do Estado de São Paulo, trabalhando como inspetor no período entre 1928 e 1932 e como delegado de ensino entre 1932 e 1959. Em sua longa carreira no magistério público paulista, as fotografias acompanharam a vida familiar e profissional desse educador. Por isso, folhear os álbuns de fotografias que ele meticulosamente colecionou e organizou ao longo de sua vida consiste em uma experiência prazerosa e, ao mesmo tempo instigante, especialmente no que diz respeito à sua trajetória profissional, pois os álbuns contêm mais de cinco centenas de fotografias relacionadas à educação primária paulista, sejam imagens retratando o exercício da inspeção, sejam aquelas sobre diferentes aspectos da cultura escolar. Dessa maneira, cada fragmento fotográfico suscita uma memória e uma representação, permitindo ao leitor da imagem se interrogar acerca dos modos de ser, representar, pensar a escola e a experiência profissional no campo da educação.

O objetivo deste texto é analisar memórias e representações da inspeção escolar no Estado de São Paulo com base em fotografias. O estudo incide sobre uma série de 566 imagens relacionadas à atuação profissional de Luiz Damasco Penna, desde sua formação como normalista englobando seu trabalho como inspetor e delegado de ensino nas regiões de Guaratinguetá e Santos, no período de 1928 a 1959, inseridas em 7 álbuns de fotografias de família. A primeira parte do texto trata do sistema de inspeção escolar no Estado de São Paulo, assinalando as atribuições de inspetores e delegados de ensino com vistas a delinear o campo de trabalho desses administradores da educação pública. Na sequência, o texto reconstitui, de forma sintética, a trajetória profissional do professor Luiz Damasco Penna, colocando em relevo sua atuação no magistério paulista. A segunda parte do texto põe em discussão memórias e representações do serviço de inspeção escolar em imagens fotográficas, considerando três dimensões do exercício da atividade inspetora: a) Viagens de visita às escolas; b) Acompanhamento da rede escolar; c) Participação em eventos e solenidades.

\section{A inspeção escolar no Estado de São Paulo}

Paulo e Warde (2013) de forma muito pertinente afirmam que o serviço de inspeção escolar, criado na Província de São Paulo em meados do século XIX, foi concebido como decorrência do processo de institucionalização da instrução primária. Inicialmente, esse serviço de fiscalização e controle das escolas e dos professores de primeiras letras esteve associado à fiscalização municipal a cargo de inspetores sem formação no magistério e sem qualificação técnica e pedagógica.

No bojo da reforma da instrução pública levada a termo no Estado de São Paulo no início do regime republicano, a inspeção e a fiscalização do ensino foram remodeladas e a inspeção passou a desempenhar o papel de organizadora da rede de ensino. Como afirma Mitrulis, "Entre a data de sua criação, 1846, e o início da década de vinte, a Inspeção Escolar do Estado alternou estruturas de organização, ora em comissão, ora individual, sempre em cooperação com os poderes municipais". (1993, p. 136).

Em 1920, a reforma da instrução pública (Lei n ${ }^{\circ} 1750$, de 8 de dezembro de 1920), denominada Reforma Sampaio Dória, introduziu modificações importantes no serviço de inspeção escolar, atribuindo-lhe o papel de renovação do sistema de ensino primário e dando ênfase a seu caráter técnico-pedagógico, além do administrativo. Visando à descentralização da administração escolar, foram criadas 15 delegacias regionais de ensino, ampliado o número de inspetores para 35 e substituídos os inspetores municipais por auxiliares de inspeção (MARTELLI, 1972; LIGEIRO, 2014). No entanto, uma nova reforma da instrução pública em 
1925 (Decreto $n^{\circ} 3.858$, de 11 de junho de 1925) reorganizou o sistema de inspeção escolar paulista, suprimindo as delegacias de ensino e criando o cargo de cinco inspetores gerais, seis especiais, 50 inspetores distritais e auxiliares de inspeção.

Em 1930, as delegacias regionais de ensino foram restabelecidas no Estado de São Paulo. Permaneceram os inspetores de distrito, e o inspetor geral, denominado delegado regional de ensino, que passou a residir na sede da delegacia, tornando-se o agente de ligação entre os inspetores de distrito e a administração central. Pelo Código de Educação de 1933 (Decreto n $^{\circ}$ 5.884, de 21 de abril de 1933) o Estado de São Paulo foi dividido em 21 regiões escolares, designando-se uma delegacia de ensino para cada região. Os inspetores escolares em número de 72, foram incumbidos de funções técnicas e administrativas, compreendendo as seguintes atribuições: cumprir e fazer cumprir as leis e regulamentos, visitar os estabelecimentos visando a inspecioná-los no que concerne à técnica e à eficiência do ensino, à idoneidade e assiduidade dos docentes, e à disciplina e higiene dos alunos; orientar os diretores e professores, no trabalho educativo, estimulando-os e assistindo-os na aplicação dos método e processos de ensino, bem como sugerindo ou efetuando demonstrações e experiências; presidir, ao menos duas vezes por ano, em cada município, a reunião mensal dos professores de escola isolada; realizar os exames finais das escolas isoladas sob sua inspeção; prestar contas ao delegado regional, cada semana, do trabalho realizado, com relatório minuciosos do roteiro seguido e dos gastos efetuados; realizar sindicâncias, por determinação do delegado regional; aplicar ou propor a aplicação de penas. (SÃO PAULO, 1933).

Ainda de acordo com essa legislação, os delegados de ensino, subordinados ao Diretor Geral do Departamento de Educação, eram os responsáveis pelos trabalhos escolares nas respectivas regiões. A escolha do delegado seria feita pelo governador dentre inspetores escolares com no mínimo 400 dias de exercício no cargo. A esses profissionais competiam as seguintes atribuições: executar e fazer executar as leis e regulamentos escolares e as determinações do Diretor Geral do Departamento de Educação; distribuir equitativamente aos inspetores escolares os serviços regulamentares e o trabalho de inspeção; visitar e inspecionar todos os estabelecimentos de ensino subordinados ao Departamento de Educação; enviar ao Departamento de Educação, até o dia 10 de cada mês, os roteiros mensais de inspeção e a prestação de contas dos gastos efetuados; propor ao Diretor Geral do Departamento de Educação a criação, localização, transferência, conversão, suspensão e supressão de escolas ou estabelecimentos de ensino; reunir anualmente os diretores dos grupos escolares da região para orientá-los, em matéria de serviço e determinar sindicâncias, propor a instauração de processos, aplicar ou propor penas disciplinares, entre outras atividades. (SÃO PAULO, 1933). ${ }^{1}$

Apesar do aprimoramento do serviço de inspeção escolar implementado no início da década de 1930, a situação da administração do ensino primário era considerada deficiente pelas autoridades educacionais, como se pode verificar no Anuário do Ensino do Estado de São Paulo de 1935 - 1936, no qual Almeida Junior, diretor geral do Departamento de Educação, assinalou vários desses problemas como a necessidade de aumentar o pessoal para o serviço interno das delegacias e solucionar a defeituosa instalação da maioria das delegacias de ensino que funcionavam em salas e saletas acanhadas de prédios de grupos escolares. $\mathrm{O}$ diretor mencionou também a necessidade de ampliação da verba de expediente atribuída a essas repartições. Para Almeida Junior, um dos grandes embaraços na atividade dos inspetores era o "adiantamento" para as despesas de viagem.

\footnotetext{
${ }^{1}$ Os critérios de nomeação de inspetores e delegados de Ensino do Estado de São Paulo foram alterados várias vezes entre as décadas de 1930 e 1970. Estudo aprofundado sobre o tema da inspeção escolar encontra-se em Ligeiro, 2014.
} 
Os que podem, gastam do seu bolso e prestam contas. Mas os que podem são a exceção. Faz-se mister uma providencia por parte do Thesouro, que permita a entrega rápida dos adiantamentos, mez por mez, a começar de janeiro afim de que não occorra, como é frequente, ficar o inspector inactivo, por falta de dinheiro. (SÃO PAULO, [1937], p. 96)².

Em consonância com a posição do diretor geral, vários delegados de ensino ressaltaram as condições precárias de trabalho dos inspetores. A opinião do prof. Onofre de Arruda Penteado, da Delegacia de Santa Cruz do Rio Pardo, registrada no mesmo Anuário, ilustra bem o teor das críticas em voga:

Judeu errante, sempre apressado, sempre aflicto, para chegar a tempo e a hora, não tem tempo para lêr, para estudar, para meditar, para orientar. O seu serviço burocrático é tão grande, a sua zona é tão vasta, como vasto é o número de mapas, roteiros guias, folhas, informes, que tem de organizar. A isso tudo, junte-se o tempo gasto nas viagens, e mais o dormir fora e comer fora de hora. E nessa azafama, forçosamente, descura-se e não se põe ao par, e nem o póde fazer, por falta de tempo, das teorias novas, que diariamente surgem em matéria de ensino. Burocratiza-se de corpo e alma. Annula-se. Automatiza-se. (SÃO PAULO, [1937], p. 81)

Fato é que o aumento do número de delegacias de ensino e de inspetores não acompanhou o ritmo da expansão do ensino primário e normal no território paulista. $\mathrm{Na}$ década de 1950, face ao movimento de renovação da escola pública primária, embora o serviço de inspeção escolar tenha sido convocado a atuar como agente da renovação educacional, os inspetores tornaram-se alvos de contundentes críticas, especialmente em relação à função marcadamente fiscalizadora e policialesca. Na década de 1960, a criação do Serviço de Orientação Pedagógica (SOP) na Secretaria de Estado da Educação e de suas regionais (SEROPs) foi o prenúncio de transformações radicais no serviço de inspeção que viria a se delinear na década de 1970. Como assevera Ligeiro (2014), essa transformação ocorreu em 1974, quando foi instituído o Estatuto do Magistério Público de $1^{\circ}$ e $2^{\circ}$ graus do Estado de São Paulo o qual substituiu o cargo de inspetor escolar pelo de supervisor pedagógico (Lei Complementar $n^{\circ} 114$, de 13 de novembro de 1974).

\subsection{Luiz Damasco Penna e seus álbuns de fotografias}

Luiz Damasco Penna tem a trajetória típica de um administrador escolar do Estado de São Paulo da primeira metade do século $\mathrm{XX}^{3}$ Partindo de uma vigorosa e inovadora formação na Escola Normal da Praça da República (marcada por Caetano de Campos e Oscar Thompson), ele foi um dos grandes difusores dos seus ensinamentos. Na administração na educação paulista revelou-se um intelectual colaborador crítico, mas respeitoso, das

\footnotetext{
${ }^{2}$ A data de publicação desse Anuário foi colocada entre colchetes, indicando se tratar de uma data provável, uma vez que não consta no documento referência sobre a data de sua publicação.

${ }^{3}$ Luiz Damasco Penna nasceu em 30 de agosto de 1896, em Taubaté-SP. Filho de João Pereira de Souza Penna e de Luiza Ester de Moura Damasco, ambos professores primários, formou-se professor pela Escola Normal da Praça (na cidade de São Paulo) em 1916 e faleceu em Santos em 1985. Estudo detalhado sobre a trajetória desse educador, ver: Pasquarelli, 2012.
} 
orientações e reformas desenvolvidas pelo alto escalão paulista. Esses grandes reformadores e pensadores como Sampaio Dória, João Toledo e Lourenço Filho aparecem não só nos seus relatórios, mas também nos seus álbuns de fotografias ${ }^{4}$.

Figura 1 - Retratos de Luiz Damasco Penna

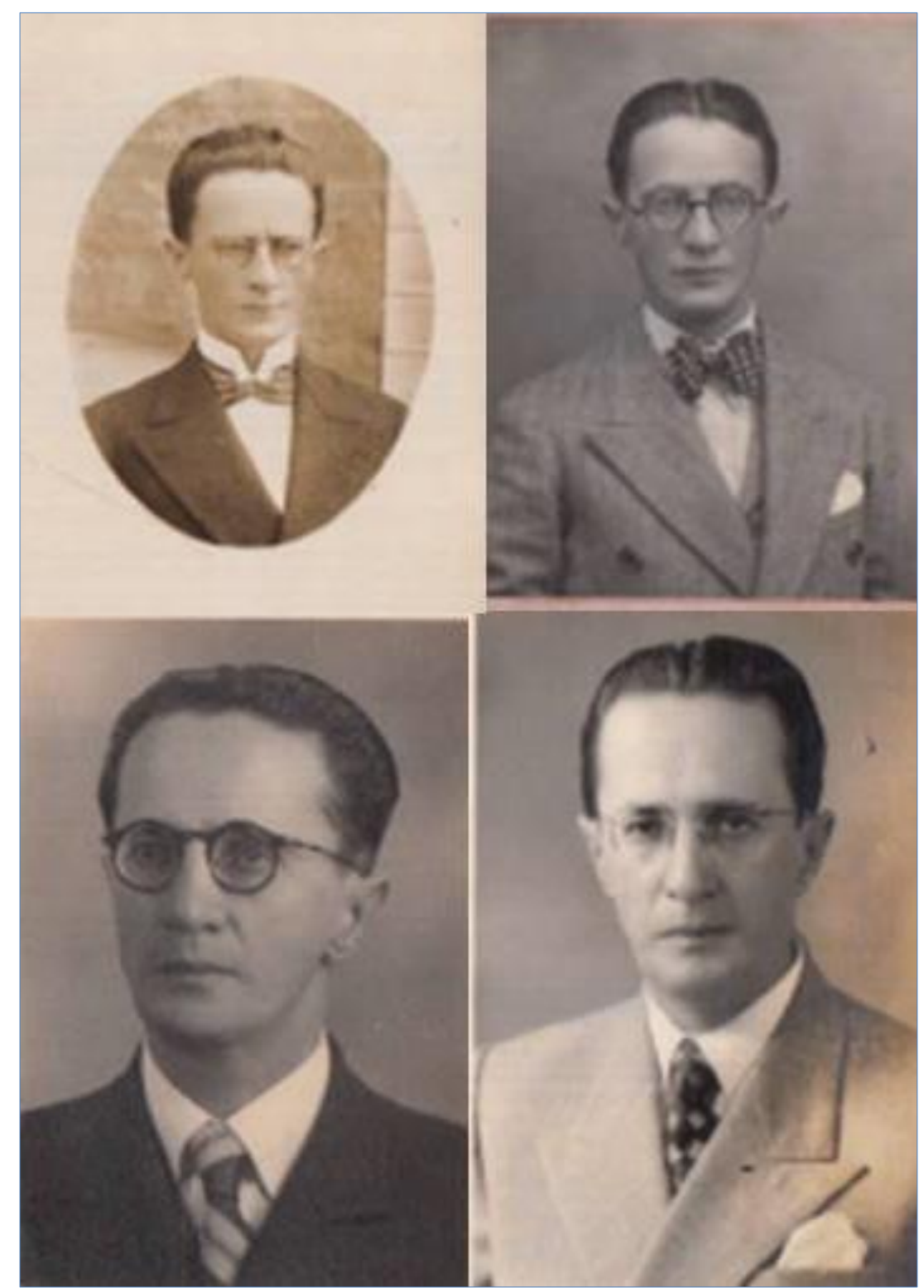

Fonte: Álbuns de fotografias de Luiz Damasco Penna. Acervo particular de Luiz Alberto Penna.

Diplomando-se em 1916 como professor primário, iniciou sua peregrinação por diferentes regiões do interior do Estado de São Paulo que estavam sendo, desbravadas. Uma visão ligeira dos problemas de educação rural nessas regiões pode ser lida em Pereira (2013).

\footnotetext{
${ }^{4}$ Durante o período em que exerceu o cargo de delegado do ensino de Santos (1932 a 1959), Luiz Damasco Penna elaborou vários relatórios anuais relatando as condições de ensino nos estabelecimentos escolares da região. No Arquivo do Estado de São Paulo encontram-se os Relatórios de 1935, 1936, 1938, 1939, 1940 e 1943. Cf. http://www.arquivoestado.sp.gov.br/site/acervo/repositorio_digital/relatorios_educacao. No Colégio "Stella Maris", localizado em Santos, encontram-se os relatórios de 1933 e 1935.
} 
A sua atuação no litoral paulista deu-se em 1928, quando foi inspetor distrital em São Sebastião, e principalmente no período de 4 de fevereiro de 1932 a 1959, como Delegado Regional de Ensino de Santos ${ }^{5}$.

Quadro 1 - Carreira do Professor Luiz Damasco Penna até sua aposentadoria

\begin{tabular}{|c|c|c|}
\hline Atividade & Local & Data \\
\hline Aluno & $\begin{array}{l}\text { Escola Normal da Praça em São } \\
\text { Paulo }\end{array}$ & 1913-1916 \\
\hline Professor & Escola Retiro em Redenção da Serra & 1917 \\
\hline Diretor de Grupo Escolar & Buquira & $20 / 04 / 1920$ \\
\hline Diretor de Grupo Escolar & Itaporanga & 1921 \\
\hline Diretor de Grupo Escolar & Catanduva & $26 / 02 / 1922$ \\
\hline Diretor de Grupo Escolar & Monte Alto & 1923 \\
\hline Inspetor distrital & S. Sebastião & $05 / 02 / 1928$ \\
\hline Inspetor distrital & Piratininga & $08 / 03 / 1929$ \\
\hline Inspetor distrital & S. José do Rio Pardo & 10/01/1931 \\
\hline Delegado de Ensino & Guaratinguetá & 24/01/1932 \\
\hline Delegado de Ensino & Santos & 04/02/1932 a 1959 \\
\hline
\end{tabular}

Fonte: PASQUARELLI, Silvio Luiz Santiago. Dissertação de Mestrado Educação, 2012. Autor: Maria Apparecida Franco Pereira.

Assim a carreira de Luiz Damasco Penna na estrutura administrativa do Estado pode ser resumida nas seguintes funções: professor (1917-1920); diretor de escolas (1920-1927); inspetor distrital (1928-1931) e delegado de ensino (1932-1959). Trabalhou em várias regiões do interior do Estado antes de fixar a sua longa trajetória no Litoral paulista. No exercício profissional, residiu muitas vezes em hotéis, locomoveu-se para as regiões em cavalo, barcos, lanchas, trens e carros. Coordenou ou participou de reuniões entre diretores, inspetores, professores, para discutir problemas da administração, métodos de aprendizagem e questões sanitárias. Ele também participou de congressos nacionais de educação, realizados em várias regiões do país.

A atuação de Penna deu-se numa época em que o Estado de São Paulo se desenvolvia rapidamente pela economia agroexportadora do café e seu interior era conquistado nas efervescentes frentes pioneiras. À medida que se adentravam pelo sertão, desenhavam-se os contornos de uma intensa vida rural. Essa economia atraía uma população cada vez maior, desejo de melhorias de condição de vida, incluindo os benefícios da escolarização. A população paulista de 837.534 habitantes em 1872 (antes da grande imigração) passa em 1900 para 2.282.279; em 1920, para 4.592.188. Em 1937, são 6.961.740 habitantes (BARROS, 1938, p.94). Durante esse desenvolvimento da economia cafeeira surgiram vários centros urbanos, alguns considerados verdadeiras capitais de suas regiões.

A área de Luiz Damasco Penna na Delegacia de Ensino de Santos - a que dedicou a maior parte de sua vida na administração pública - foi o litoral paulista, a extensa faixa de terra entre Ubatuba, ao norte, e Cananéia ao sul, podendo ser subdividido entre Litoral Norte,

\footnotetext{
${ }^{5}$ Em 5 de julho de 1956, a comunidade santista reuniu em jantar festivo para homenageá-lo. O jornal “A Tribuna" de Santos relembra esse evento na seção "No tempo dos nossos avós" de Olao Rodrigues (23/05/1976). No álbum 4, fl.19, está colada uma foto dessa comemoração (onde aparecem Sólon Borges dos Reis, o prefeito Antonio Feliciano da Silva, o bispo diocesano D.Idílio José Soares e outras personalidades ilustres da cidade).
} 
Baixada Santista e litoral sul (incluindo o Vale do Ribeira, que adentra o interior) ${ }^{6}$. A faixa litorânea paulista tinha características socioeconômicas específicas: antigos estágios de desenvolvimento ao longo dos séculos marcados por busca do ouro e cultura do arroz, no extremo sul; fabrico da aguardente no litoral norte e, em todo o litoral, a economia bananicultora, a agricultura de subsistência e a pesca que deram impulso lento à região. As populações distantes dos centros urbanos - ribeirinha dos rios e do litoral - viviam esparsas e isoladas necessitando da escola para atingir a civilização e o progresso. Essas regiões que vivenciaram na primeira metade do século XX a ausência de ferrovias e rodovias dependiam dos transportes fluviais e das caminhadas por terra (PEREIRA, 2010, p.186-191).

Figura 2- Mapa da Região Escolar de Santos

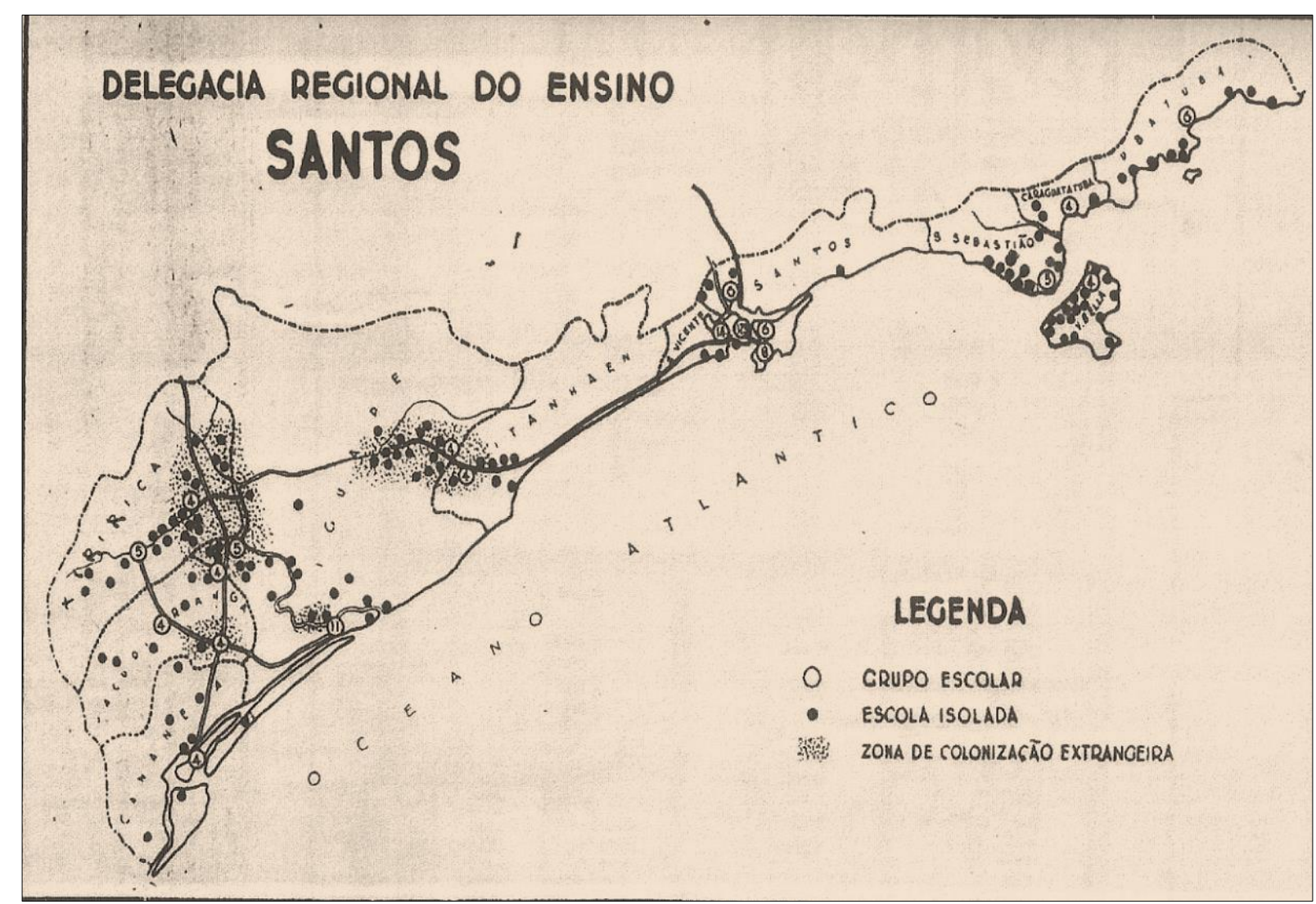

Fonte: Annuario do Ensino do Estado de São Paulo, 1935-1936, p. 81

A Delegacia de Ensino de Santos, onde Luiz Damasco Penna exerceu o cargo de delegado de ensino por 27 anos, era constituída por cinco distritos escolares que foram se compondo de várias maneiras: Município de Santos; Município de Santos e São Vicente; Município de Santos, Itanhaém e Iguape; Municípios de Iguape, Cananéia, Jacupiranga e Xiririca; e Municípios de São Sebastião, Vila Bela, Ubatuba e Caraguatatuba, como mostra a figura 2. Compreendia, pois, uma zona escolar litorânea caracterizada pela dispersão das escolas primárias. Como bem assinalou Denise Silva:

\footnotetext{
${ }^{6}$ Essas áreas em 1991 compreendem: 1) O Vale do Ribeira, no Estado de S. Paulo, e o litoral sul abrangem 23 municípios: Apiaí, Barra do Chapéu, Barra do Turvo, Cajatí, Cananéia, Eldorado, Iguape, Ilha Comprida, Iporanga, Itaóca, Itapirapuã Paulista, Itariri, Jacupiranga, Juquiá, Juquitiba, Miracatu, Pariquera-Açú, Pedro de Toledo, Registro, Ribeira, São Lourenço da Serra, Sete Barras e Tapiraí. 2) A Baixada Santista é a porção litorânea mais povoada e industrializada, cobrindo os municípios de Santos, Guarujá, Bertioga, Peruíbe, Itanhaém Cubatão, São Vicente e Praia Grande. 3) O litoral norte compõe-se dos municípios de Ubatuba, Caraguatatuba, Ilhabela e S. Sebastião. (IBGE, apud DIEGUES 2007, p.2)
} 
Embora não fosse provida de um grande número de unidades escolares (possuía cerca de 402 escolas em 1936), a delegacia de Santos era a segunda maior em porcentagem de atendimentos à população, recebendo cerca de $60 \%$ das crianças. Atender mais da metade das crianças numa região onde grande parte dos estabelecimentos escolares, cerca de $80 \%$, era composta pelas escolas isoladas, colocava a delegacia regional de Santos em evidência, tornando-a um verdadeiro "arquipélago" de "ilhas do saber". (2004, p. 45).

Nessa zona escolar, o delegado de ensino e os inspetores enfrentavam vários problemas como a distância dos estabelecimentos escolares, o pequeno número de inspetores, a precariedade das estradas e dos meios de transportes e o isolamento das escolas em muitas localidades. Foi nesse contexto geográfico, educacional e sociocultural peculiar que Luiz Damasco Penna exerceu suas atividades na liderança regional da administração do ensino público no litoral paulista.

\subsection{O acervo documental}

O acervo documental deixado pelo Prof. Luiz Damasco Penna referente à sua trajetória profissional foi em parte distribuído em vida. Pelo que localizamos até agora, cópias de relatórios da Delegacia de Ensino e sua biblioteca pessoal foram doadas ao Colégio "Stella Maris", em Santos. Entretanto o prof. dr. Luiz Alberto Penna, seu neto, é possuidor de um acervo importantíssimo para a historiografia da educação paulista: são sete álbuns de imagens relacionadas à vida pessoal e profissional do delegado de ensino Luiz Damasco Penna. Os álbuns são constituídos por diversos materiais iconográficos e alguns textuais (fotos, xerox de revistas, cartões postais de vários tamanhos e cor, folhetos vários, como programas de cerimônias e diversos "santinhos" fúnebres), como é possível observar na figura 3.

Figura 3 - Tipos de fotografias encontradas nos álbuns do Prof. Luiz Damasco Penna

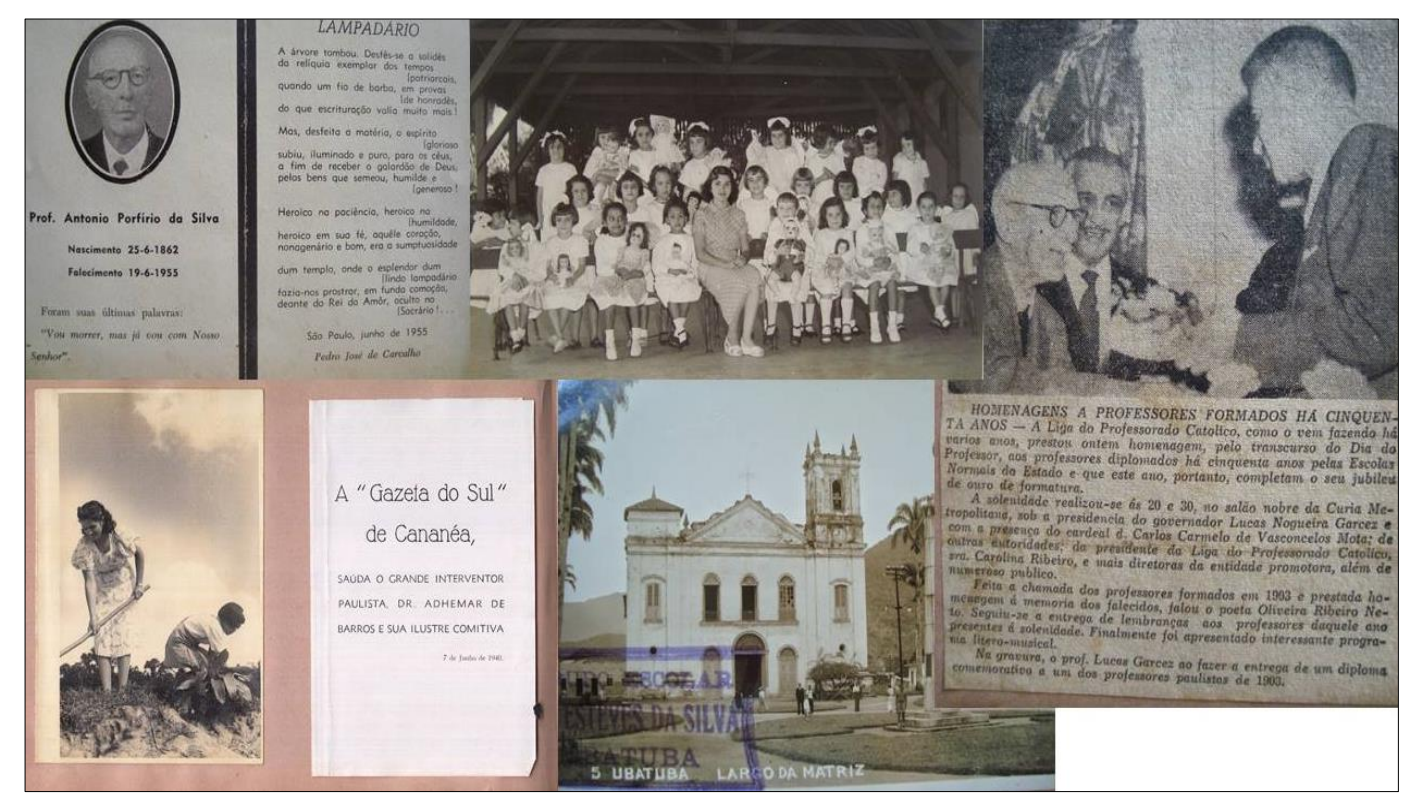

Fonte: Álbuns de fotografias de Luiz Damasco Penna. Acervo particular de Luiz Alberto Penna. 
Os sete álbuns abrigam 787 imagens, a maioria delas, isto é, 72\% (566 fotografias) são relacionadas a escolas e a atividades educacionais. ${ }^{7}$ Algumas das imagens fotográficas são de fotógrafos profissionais, porém, a maioria é de máquina comum. Os referidos álbuns foram mandados confeccionar, cujo suporte é feito de páginas de cartolina, com folhas divisórias de papel de seda. Todos os álbuns têm a mesma dimensão $(32 \mathrm{~cm} \times 22,5 \mathrm{~cm})$ e possuem capas de cor preta com pintas verdes, tipo carijó. Apenas o de número 1 possui capa de cor vinho, lisa. Nota-se uma relativa organização, dentro de cada um, obedecendo a uma ordem cronológica. Exceção é verificada no álbum de número 7, no qual aparecem fotos da década de 1910 e 1920 que deveriam estar no álbum n. 1, dando a impressão de que foram encontradas e organizadas depois. As imagens em sua maioria encontram-se coladas, porém há diversas presas por cantoneira, necessitando esse material de restauração.

Quadro 2- Composição dos álbuns de fotos de Luiz Damasco Penna ( ${ }^{\circ}$ de imagens)

\begin{tabular}{|l|l|l|l|}
\hline Número do Álbum & \multicolumn{1}{|c|}{$\begin{array}{c}\text { Atividades de } \\
\text { Ensino }\end{array}$} & $\begin{array}{c}\text { Familiares e } \\
\text { amizades }\end{array}$ & Total imagens \\
\hline Um & 49 & 51 & 100 \\
\hline Dois & 97 & 16 & 113 \\
\hline Três & 47 & 59 & 106 \\
\hline Quatro & 92 & 4 & 96 \\
\hline Cinco & 122 & 0 & 122 \\
\hline Seis & 101 & 25 & 126 \\
\hline Sete & 58 & $36+30$ postais $^{8}$ & 124 \\
\hline Total geral & 566 & $191+30$ & 787 \\
\hline
\end{tabular}

Fonte: Álbuns de fotos de Luiz Damasco Penna. Autora: Maria Apparecida Franco Pereira.

O que teria levado Luiz Damasco Penna a colecionar esse grande número de fotografias escolares? Por certo também concorreu o exercício profissional. É possível que algumas dessas fotografias tenham sido produzidas e colecionadas em atendimento às exigências do Departamento de Educação, pois, nas décadas de 1930 e 1940, a administração geral do ensino do Estado de São Paulo deu especial atenção aos relatórios anuais de inspetores e delegados como instrumento de acompanhamento da renovação pedagógica com base nos princípios da Escola Nova implementada no estado. (SOUZA, 2009).

Os relatórios deveriam atestar as condições físicas das escolas, a eficiência do ensino e todo tipo de problema identificado nos estabelecimentos escolares. Os delegados regionais foram instruídos, por meio de circulares, a elaborar relatórios abrangentes e detalhados sobre os mais diversos aspectos da vida escolar de sua respectiva região, apresentando dados estatísticos e elementos textuais e visuais para comporem os relatórios como quadros, tabelas, gráficos, desenhos, mapas e, especialmente fotografias consideradas como registros comprobatórios. ${ }^{9}$ Contudo, também, é possível que o acervo fotográfico reunido pelo professor Penna tenha decorrido de sua predileção pela fotografia e seu senso aguçado de organização e documentação, identificados nos relatórios anuais da Delegacia de Santos elaborados por ele e em toda a sua trajetória profissional, como bem demonstrou Silvio Pasquarelli (2012).

\footnotetext{
${ }^{7}$ Estudo inicial sobre os álbuns de fotografias de Luiz Damasco Penna foi realizado por Edson Rossetti Alves. Ver: Alves, 2015.

${ }^{8}$ Postais acrescidos, alguns sem ligação evidente a atividades profissionais, como em álbum anterior.

${ }^{9}$ Estudos sobre esses relatórios foram realizados por Souza, 2009 e Celeste Filho, 2012. O Arquivo Público do Estado de São Paulo possui 64 desses relatórios que estão disponibilizados on line no site: <http://www.arquivoestado.sp.gov.br/educacao/instrucao.php>. Apesar do elevado número de fotografias escolares reunidas por Luiz Damasco Penna, poucas foram incorporadas nos relatórios que ele elaborou sobre aa atividades anuais da Delegacia de Santos, com exceção do relatório de 1936.
} 
Embora Penna tenha falecido em 1985, as atividades retratadas nos álbuns vão até $1960^{10}$, ano em que se aposenta. São memórias coletivas em diferentes momentos de sua vida. Os quase trinta anos de vida dedicados à tradução de obras de educação para a Editora Nacional (onde seu irmão João Batista dirige a Biblioteca de Educação), o magistério superior em Santos (1958-1968), lecionando Administração Escolar para o curso de Pedagogia da Faculdade de Filosofia, Ciências e Letras (da hoje Unisantos) e suas atividades como membro de entidades de classe (CPP e a Anpae, das quais é um dos fundadores em 1966) quase não aparecem nos álbuns de fotografias.

Dessa maneira, as fotos relativas a atividades de magistério ou inspeção podem ser divididas em três blocos: sobre sua formação, o período da carreira antes de 1932 quando atuou como professor, diretor e inspetor distrital, e, como delegado de ensino com atuação no litoral norte (período fartamente documentado em fotografias, sobretudo até parte do álbum 5 e no litoral sul, nos álbuns 5 e 6).

Vale destacar aqui a composição do álbum de n. 1, porque é bem variada e diferente dos outros na sua organização. Esse álbum testemunha o seu ponto de partida na formação na Escola Normal da Praça da República (1912-1916) e vai até 1936, quando apresenta fotos de grupos de pessoas e alunos de alguns lugares onde trabalhou, antes de assumir a Delegacia Regional de Santos em 1932 (Redenção, Óleo, Piratininga, Monte Alto etc.) locais onde atuou como professor e sobretudo como Diretor. Encontram-se também nesse álbum inúmeras fotos familiares. Constantemente coloca fotos de seu irmão João Batista (1909-1990), que se tornou nome importante no setor de publicação de obras pedagógicas, na Editora Nacional, e de seu irmão de criação, Zenon Cleantes de Moura, professor na Escola Experimental da Praça e mais tarde, primeiro delegado de Santos, na fase inicial de implantação (nomeado em 21 de abril de 1922). Em muitas fotos aparece, junto a Penna, a companheira e professora atuante, Maria Henriqueta da Silva, com quem casou em 1919.

No conjunto dos sete álbuns, as legendas em geral são incompletas: há fotos sem título ou data, denotando que são do cotidiano ${ }^{11}$ recolhidas para a memória do organizador, mas não refletindo suficientemente o valor de registro documental que provavelmente seria o desejo do professor Penna.

De um modo geral, pode-se dizer que os sete álbuns de fotografias de Luiz Damasco Penna oferecem inúmeros elementos para o estudo da cultura escolar e que eles permitem constatar os seguintes aspectos:

[1] a presença maciça de mulheres professoras, enquanto os inspetores retratados são na sua totalidade homens; portanto em funções administrativo-educacionais.

[2] que a rua é o local que torna a escola mais visível (através dos desfiles, das fachadas das escolas, das apresentações dos grupos de escoteiros etc.).

[3] as atividades extraclasse dos alunos são registradas em número bem grande, seja em desfiles ou atividades cívicas, esporte ou em exposições de trabalhos manuais, serviços de horta etc.

[4] visitas do Inspetor em sala de aula, com sua atuação e da professora.

[5] formas e dificuldades de locomoção (cavalo, barcos, carro atolado) ${ }^{12}$.

\footnotetext{
${ }^{10}$ Identificou-se apenas uma fotografia de 1960.

${ }^{11}$ Não só as fotos de familiares e de pessoas do convívio familiar. Neste caso, quando foi preciso, consultouse o dr. Luiz Alberto Penna.

12 Interessante que Luiz Damasco Penna não tenha incluído nos álbuns nenhuma foto sobre via férrea, dado o fato de ter utilizado muito este meio de transporte em suas atividades profissionais. No relatório da Delegacia de Santos, de 1940, Penna afirmou: "Os meus registros acusam 57.149 Kms de viagem, dos quais 25.302 de viagem a São Paulo, em serviços do cargo e 31.847 pela região, assim distribuídos: em estrada de ferro 14.674, em estrada de rodagem 8.525, em embarcações 8.090, a cavalo 558”. (RELATÓRIO DA DELEGACIA DE SANTOS, 1940, p. 4).
} 
Na direção da Delegacia de Ensino de Santos, Penna dialogou com diretores de grupos escolares, com professores, com seus auxiliares de inspeção, com outros delegados de ensino. Assim, muitas imagens dos Álbuns de fotografias desse educador são de reuniões em que podem ser reconhecidos inspetores da região de Santos, como Turiano Flávio de Andrade, Primo Ferreira, Suetônio Borges Bittencourt, além de diretores como Pedro Crescenti.

As visitas e reuniões com autoridades educacionais foram temas privilegiados nas fotografias reunidas por Damasco Penna (sobretudo no álbum de n. 4), como se pode observar nas fotos da figura $4 \mathrm{em}$ que aparece Fernando de Azevedo (no centro da foto à esquerda), e em outra do dr. Luiz Gonzaga Fleury, chefe de Serviço da Diretoria de Ensino, ao qual Penna acompanhou, de 16 a 31 de maio de 1936, na zona de Registro.

Figura 4 - Reunião com Fernando de Azevedo (1933) e visita do Professor Fleury em Registro (1936).

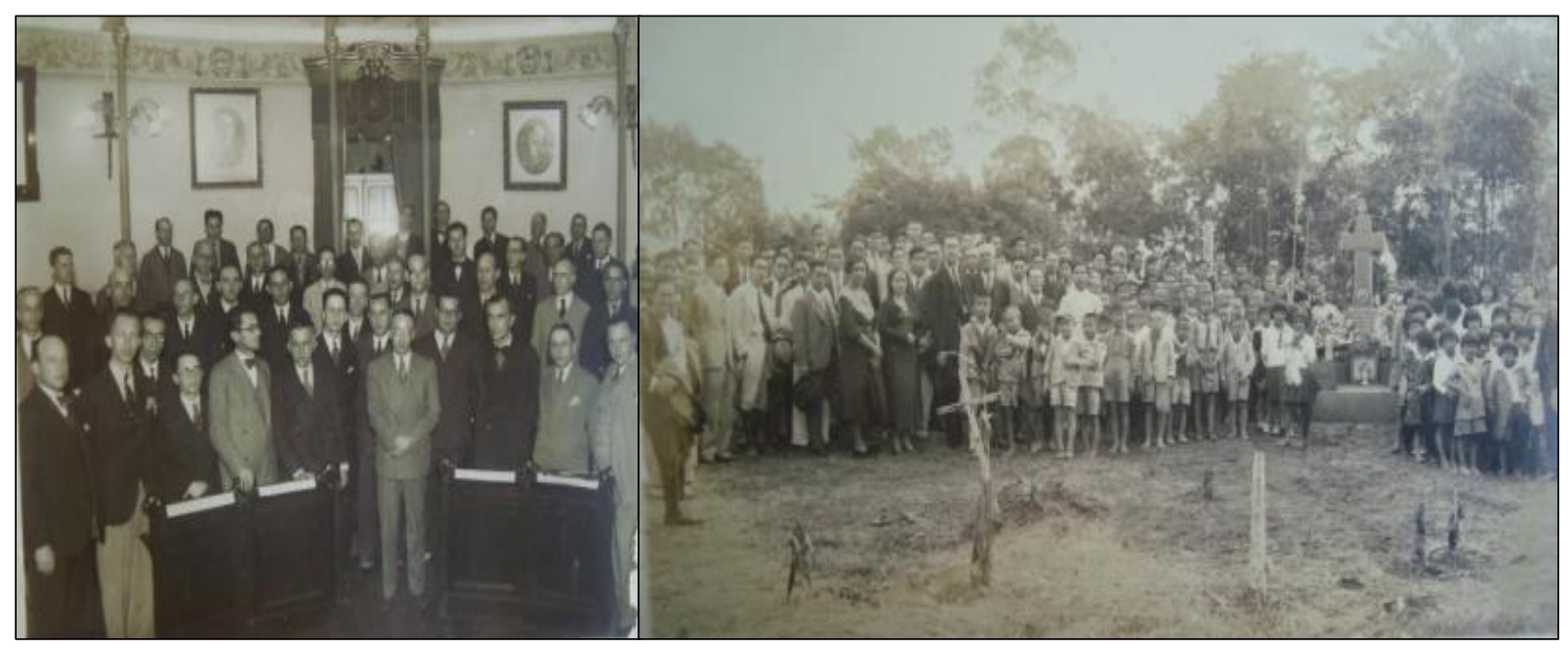

Fonte: Álbuns de fotografias de Luiz Damasco Penna. Acervo particular de Luiz Alberto Penna.

Muitas imagens são de prédios de grupos escolares ou de escolas isoladas. Não há monumentalidade nem, de modo geral, construções desleixadas. Há muitos postais ${ }^{13}$, mostrando as cidades ou os locais entorno das escolas. São interessantes as fotos de atividades dentro de classe com visita do inspetor, porém a maioria das fotos são feitas em lugar aberto, pois as máquinas fotográficas não estavam no início aparelhadas para interiores. Algumas fotos (de formatura ou de eventos festivos) são tiradas por fotógrafos profissionais, porém a maioria é de máquinas de amadores.

Destaca-se ainda, a presença da imigração japonesa na zona do Ribeira, privilegiadas no registro iconográfico de Penna, sobretudo nos álbuns 6 e 7, nos quais constam várias imagens da atuação dos japoneses no campo de experiência, nas escolas, no acompanhamento a visitas de autoridades nipônicas e estrangeiras, festividades artísticas e escolares. ${ }^{14}$ Algumas dessas imagens reunidas na figura 5 destacam-se as imagens à esquerda a casa do fazendeiro (acima) e a de um colono (abaixo) e, à direita, alunos da colônia japonesa de Registro.

\footnotetext{
${ }^{13}$ Há também muitos postais das metrópoles onde se realizavam os Congressos.

${ }^{14}$ Como muitas fotos de atividades na escola não têm referência, pode-se perceber que são de atividades nas regiões de presença japonesa por alguns traços da antiga arquitetura japonesa nos frontões do edifício, com a formação de cumeeiras. A cumeeira é um complemento do telhado necessário para tapar o vão que se forma entre as duas águas, para evitar a entrada da água da chuva ou outros elementos.
} 
Figura 5- Residência de japoneses no Vale do Ribeira e alunos do G.E. de Raposa, Registro, 1938

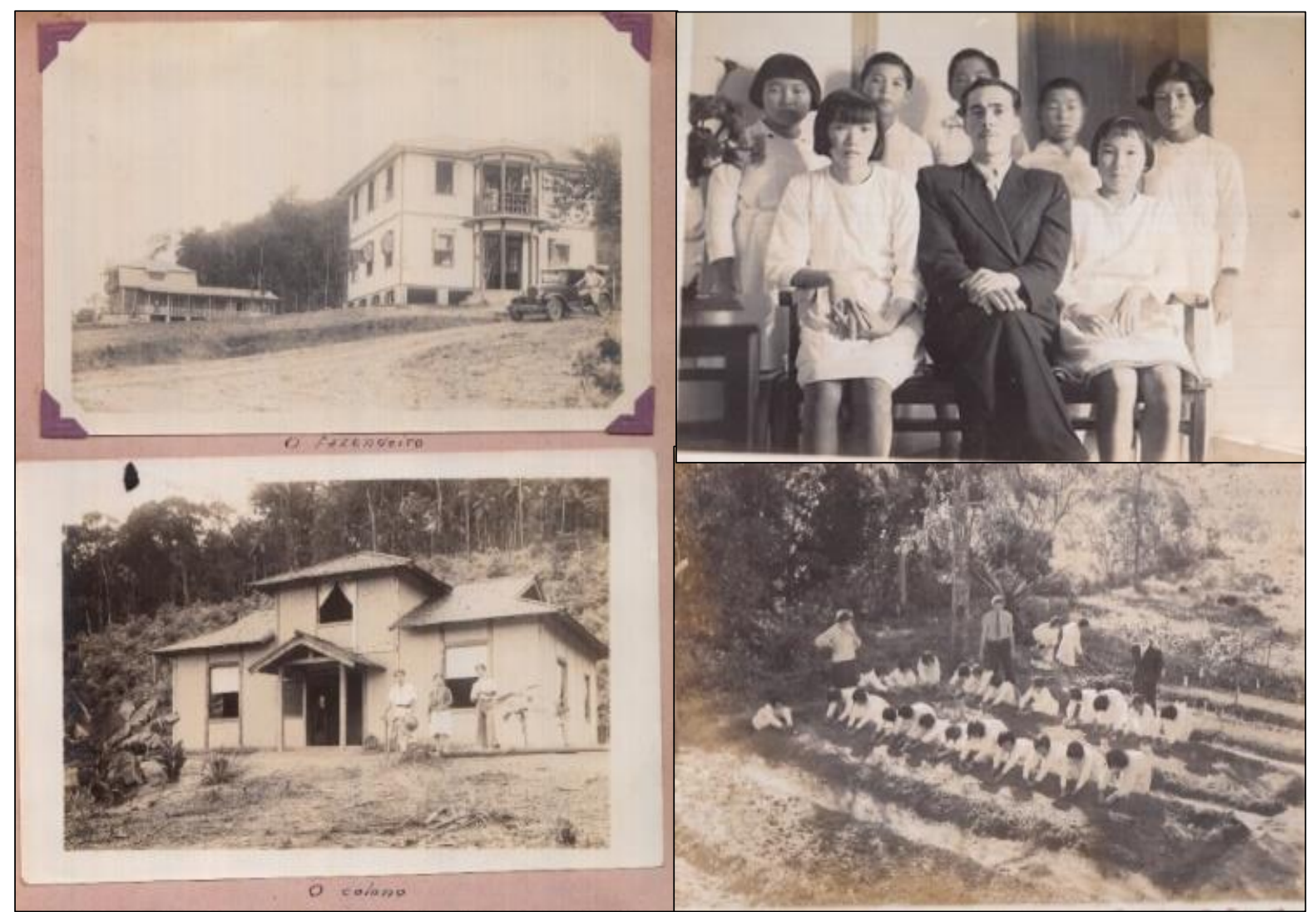

Fonte: Álbuns de fotografias de Luiz Damasco Penna. Acervo particular de Luiz Alberto Penna.

Dessa maneira, podemos afirmar que nesse rico conjunto iconográfico, memória e representação se entrelaçam nas múltiplas faces da inspeção e da vida escolar.

\section{Memórias e representações da inspeção escolar}

O conjunto iconográfico delimitado para a análise neste texto compreende 566 imagens fotográficas que podem ser classificadas como fotografias escolares nos termos indicados por Bencostta (2011, p. 400), isto é, "aquelas produzidas no ou referidas ao universo escolar". Misturadas às fotografias familiares, elas constituem memórias de uma trajetória em que a atividade profissional foi inseparável de outras ocasiões memoráveis da vida familiar. Se, como observou Susan Sontag, "Por meio de fotos, cada família constrói uma crônica visual de si mesma" (2005, p. 19), nos álbuns de fotografias de Luiz Damasco Penna a sua atuação como inspetor e delegado de ensino e a rede escolar da região de Santos são partes fundamentais do discurso visual dos álbuns de família que ele ajudou a colecionar e a arquivar. Na sequência deste texto buscamos problematizar essas imagens como memória e representações da educação.

Jacques Le Goff (1994) ressaltou o caráter revolucionário desempenhado pela fotografia na memória social a partir do seu aparecimento no século XIX. Como observa esse autor a fotografia multiplica e democratiza a memória, "dá-lhe uma precisão e uma verdade visuais nunca antes atingidas, permitindo assim guardar a memória do tempo e da evolução cronológica". (1994, p. 466). 
Num trabalho que constitui no Brasil um marco na reflexão sobre a fotografia como fonte histórica, Boris Kossoy assinala a importância de se levar em conta os elementos implicados na produção da fotografia, isto é, o assunto, o fotógrafo e a tecnologia (KOSSOY, 1980, 2001). Este autor tem chamado a atenção para as múltiplas faces e realidades da fotografia, indicando que, além da dimensão visível, o testemunho, que está imóvel no documento, ela encerra outras faces invisíveis, ou seja, a vida das situações e dos homens e mulheres retratadas. Por isso, para esse autor, é importante que o historiador, ao utilizar fotografias como fontes, leve em conta que elas são uma representação elaborada a partir de condições culturais e critérios estéticos e técnicos, o que implica cuidados metodológicos imprescindíveis, dado que o índice e o ícone presentes na fotografia não podem ser desvinculados do processo de construção da representação. Como decorrência, é preciso estar atento para as leituras que os receptores fazem delas ao longo do tempo, assim como para a interpretação do historiador (KOSSOY, 2005, p. 41).

De acordo com Possamai (2008, p. 254): “Como representações do real, as imagens visuais constroem hierarquias, visões de mundo, crenças e utopias e, neste sentido, podem constituir-se em fontes preciosas para a compreensão do passado". Na mesma direção, como bem nos lembra Andrade (1990), a fotografia é uma fonte que demanda do historiador um novo tipo de crítica. Parafraseando Jacques Le Goff, essa autora propõe considerar a fotografia simultaneamente imagem / documento e como imagem / monumento. Essa dupla dimensão implica levar em conta a fotografia como referente, marca da materialidade passada, e como símbolo, "aquilo que, no passado, a sociedade estabeleceu como a única imagem a ser perenizada para o futuro". (ANDRADE, 1990, p. 23). Além do trabalho de interpretação, é importante que o pesquisador constitua séries temáticas para o exame do conjunto iconográfico selecionado para estudo (LEITE, 1993, POSSAMAI, 2008).

Em relação ao passado da educação, as fotografias escolares constituíram-se em um gênero fotográfico difundido no século XIX, em decorrência da constituição dos sistemas nacionais de ensino. As classes escolares, retratos e fotos de formatura fomentaram o comércio de fotografias tornando a escola objeto importante do olhar fotográfico (BENCOSTTA, 2011; LEITE, 2005). A esse respeito, Abdala (2013) ressalta o apelo laudatório e memorialístico da fotografia com temática escolar. De acordo com essa autora, a fotografia de escola "engloba os prédios das escolas, as atividades desenvolvidas, mas fundamentalmente as fotografias que estabelecem uma relação de identificação entre o aluno, sua família e a sociedade e a escola". (ABDALA, 2013, p. 102).

No caso dos Álbuns de Luiz Damasco Penna, as fotografias relacionadas à educação permitem vários rearranjos em subséries temáticas como fachadas de escolas, turmas de alunos, comemorações cívicas, grupos de escoteiros, desfiles patrióticos, escolas rurais, quadros de formatura, entre outros. No entanto, para as finalidades deste texto, reagrupamos as imagens em três grupos temáticos que expressam o exercício da inspeção escolar: a) Viagens de visita às escolas; b) Acompanhamento da rede escolar, c) Participação em eventos e solenidades.

\subsection{Viagens de visita às escolas}

Até a década de 1960, a visita às escolas consistia em uma das mais importantes atividades do serviço de inspeção escolar no Estado de São Paulo. Por meio das visitas, inspetores e delegados do ensino fiscalizavam o trabalho de diretores, professores $\mathrm{e}$ funcionários dos grupos escolares e dos professores das escolas isoladas, verificando a 
regularidade e a eficiência do ensino, a frequência dos alunos e dos professores, o cumprimento dos programas, a metodologia no ensino das matérias, as condições dos prédios escolares e dos materiais didáticos, a aplicação dos exames finais. Eles orientavam diretores e professores sobre o cumprimento dos deveres, realizavam reuniões pedagógicas e divulgavam práticas desejáveis. Como bem ressaltou Denise Silva (2004), delegados e inspetores eram vistos como representantes do Estado, autoridades educacionais revestidas de poder e competência técnica. Os inspetores fiscalizavam e eram fiscalizados; nas escolas registravam suas impressões nos Termos de Visita e para a Delegacia de Ensino apresentavam contas mensalmente, além de cartões de visita e relatórios.

No entanto, a visita aos estabelecimentos de ensino compreendia um desafio constante devido às condições de funcionamento da inspeção escolar: havia um número restrito de inspetores para atender um grande número de unidades escolares de cada região, além do tamanho dos municípios, a dificuldade de comunicação entre as localidades devido às más condições das estradas e as despesas de condução.

No relatório anual de 1936 apresentado por Luiz Damasco Penna ao Diretor do Ensino Educação, ele informou que a média de visitas dos inspetores por classe na região de Santos fora de 3,3 e por escola 4,1. A quilometragem percorrida pelos inspetores foi de 35.852 kilometros. Informou ainda as visitas que ele próprio fizera: "Visitei 28 escolas rurais, 178 classes de grupo, 60 de escolas particulares e 24 de outras escolas, num total de 290 unidades escolares". (RELATÓRIO DELEGACIA DE SANTOS, 1936). No relatório de 1938, Penna discorreu com detalhes sobre os problemas vivenciados por ele e pelos inspetores escolares da delegacia de Santos nas viagens de visita às escolas da região:

Pois bem, em 1937, os inspetores, eu inclusive, nós seis, viajamos 44.455 kilometros, dos quais, 22.485 em estrada de ferro e 4.547 de automóvel, como os demais inspetores do Estado; mas dos quais 2.583 a cavalo e 14.840 em embarcações fluviais e marítimas; aéreas até, pois, fiz eu uma viagem de $111 \mathrm{~km}$ em hidroplano.

Dois mil e quinhentos quilômetros a cavalo e perto de quinze mil quilômetros em embarcações, assim, singelamente escritos, são uma coisa; viajados, já são outra para quem os viaja. (RELATÓRIO DA DELEGACIA DE SANTOS, 1938).

Dada a centralidade das viagens no trabalho de inspeção, o professor Penna buscou reunir fotografias retratando os meios de transporte utilizados por ele e os demais inspetores e os hotéis que lhes serviam de pouso e descanso.

A Figura 6 exemplifica as viagens a cavalo, meio de uso comum dos inspetores no litoral e no interior do Estado de São Paulo. Apesar da galhardia apresentada na imagem, a descrição do próprio professor Penna possibilita apreender as dificuldades do uso desse meio de transporte:

Entre uma excursão de légua em bom animal e bôa estrada e a equitação grotesca e perigosa a que nos submetemos aqui, vai muito. Não há, de ordinário, estradas nem mesmo caminhos. Há trilhos, muitos dos quais no alcantilado da costeira e bastantes para a páta da montaria. Assim são horas e horas, por veses, frequentissimamente debaixo de aguaceiro comum á costa, da soalheira própria da região, 
de temporais ríspidos e perigosos. Nem sempre a segurança de um ajantarado (grifos do autor) de nova espécie, ás seis e sete horas da tarde e de pouso acima da esteira. Não se contam os riscos, comuns, de um falseio do animal, de estirões a pé, subindo como quem sobe escáda, com ajuda, ás veses, tanto de pés como de mãos, os vadeios de rios e barras no escuro e no incerto da noite. (RELATÓRIO DA DELEGACIA DE SANTOS, 1938).

Figura 6- Luiz Damasco Penna montado a cavalo para trabalho, c. 1940.

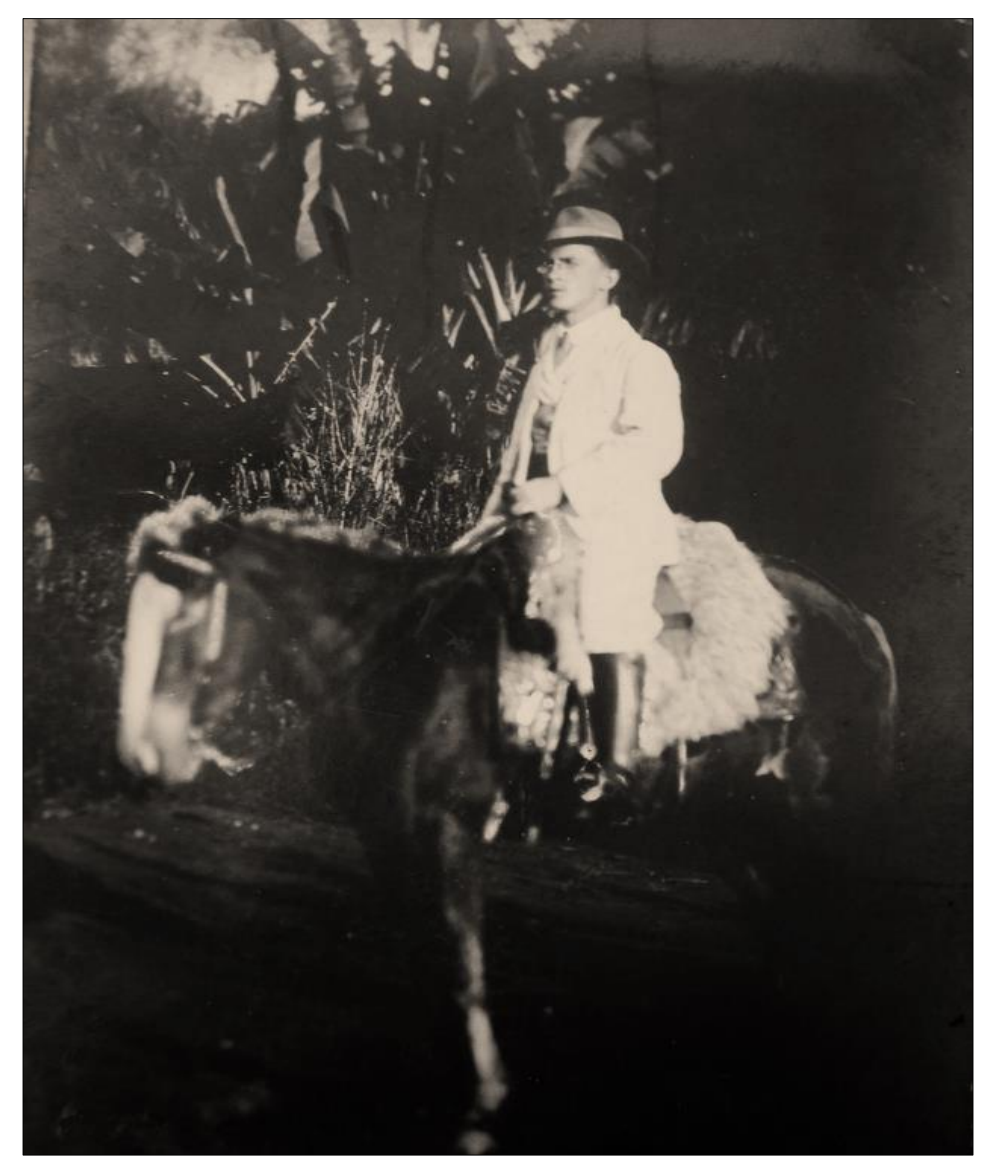

Fonte: Álbuns de fotografias de Luiz Damasco Penna. Arquivo particular de Luiz Alberto Penna.

No litoral, outro meio de transporte bastante utilizado pelos inspetores era a embarcação. A respeito do transporte marítimo na região de Santos, o professor Penna teceu considerações detalhadas no Relatório de 1938 assinalando os diferentes tipos de embarcação utilizados por ele e pelos inspetores nas viagens de inspeção e as agruras das viagens marítimas e fluviais:

Do mar não há que se diga. A rubrica - embarcações - do Boletim Resumo Mensal compreende um museu retrospectivo de arte náutica, desde os luxuosos paquetes da Blue Star Line, que tocam em São Sebastião, mas cujo embarque nos é defeso pelo alto custo da passagem, até a mais remota piroga deixada ainda como último 
vestígio tupi. Dentro dessa curva cabem navios costeiros de segunda, terceira e decima ordem, navios fluviais, de róda, do tempo do império, pequenos veleiros do sul, desses que dão crônicas aos jornais e amanhecem um dia arribados, a bordada desbeiçada pelo cachação de vaga, cutters e hiates de mil espécies, minúsculos barquinhos de pesca - um porão frigorífico e um motor em cima d'agua e na taboa que sóbra o passageiro - uma infinidade de coisas nas quais são feitos aqueles quinze mil quilômetros, nos quais são vividas muitas mil horas de todas as incertezas e todos os desconfortos. (RELATÓRIO DA DELEGACIA DE SANTOS, 1938, p. 6-7).

A imagem da figura 7 é elucidativa a esse respeito apresentando o desembarque do professor Penna juntamente com outros homens em alguma parada no litoral paulista. A presença de fotografias do veleiro Almirante Saldanha e do cúter Atlas nos álbuns de Damasco Penna indiciam a relevância das embarcações no serviço de inspeção no litoral.

Figura 7- Embarcações utilizadas pelos delegados e inspetores na região escolar de Santos

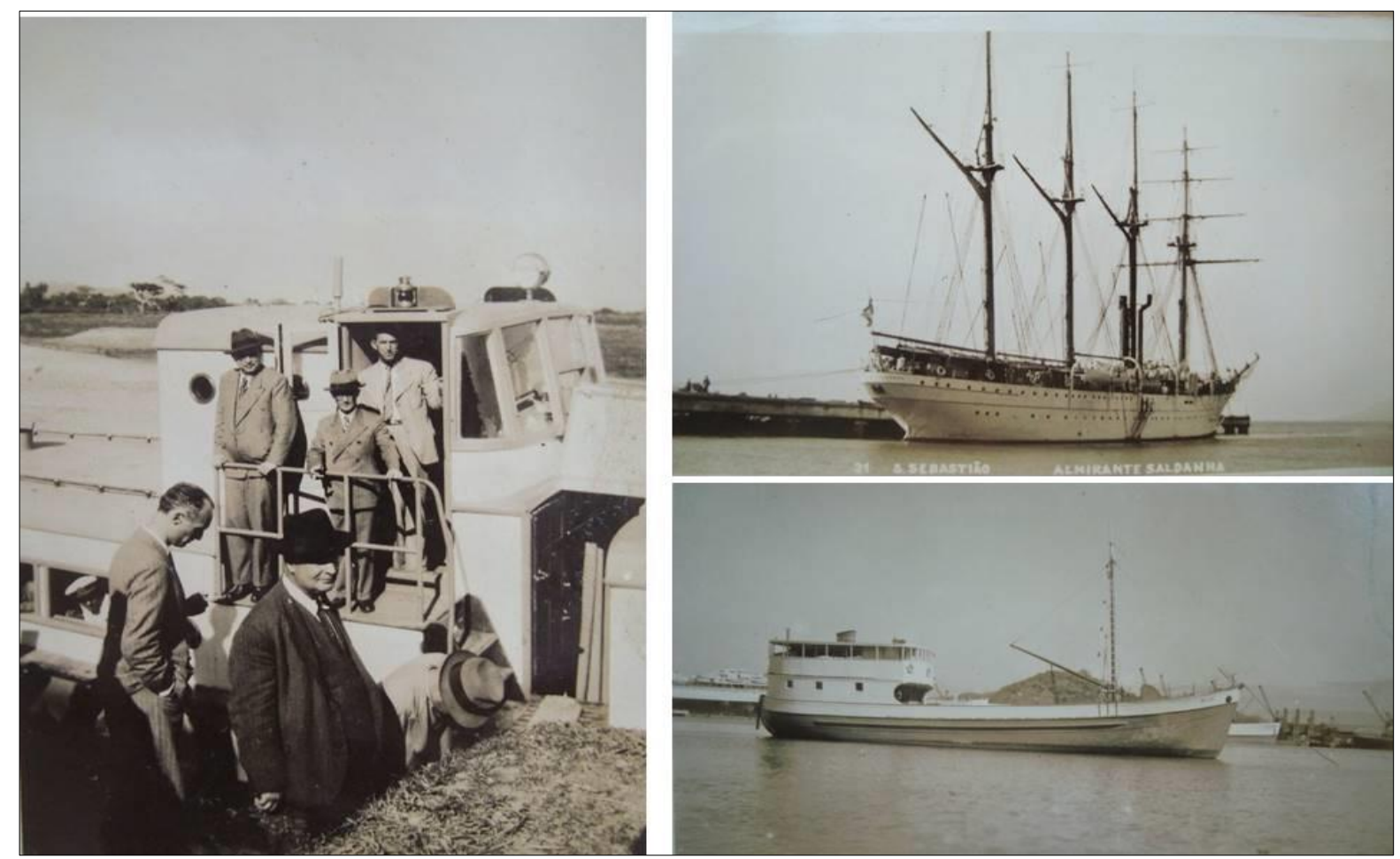

Fonte: Álbuns de fotografias de Luiz Damasco Penna. Acervo particular de Luiz Alberto Penna

Ao apreciar os álbuns de fotografias de Luiz Damasco Penna, chamou-nos a atenção algumas imagens de fachadas de hotéis em cartões postais e fotografias. Não por acaso, o professor Penna guardou essas imagens, que correspondem a aspectos importantes das viagens de inspeção. Depois de horas de viagem ou de um dia de visita nas escolas da região, este tipo de hospedagem servia a inspetores, delegados e até mesmo a professores para descanso e repouso. Na figura 8, os detalhes da edificação do Hotel Bela Vista salientam o casarão de amplas janelas e porta de madeira contornado por árvores e colinas ao fundo. 
Figura 8 - Hotel Bela Vista, Vila Bela (cartão postal)

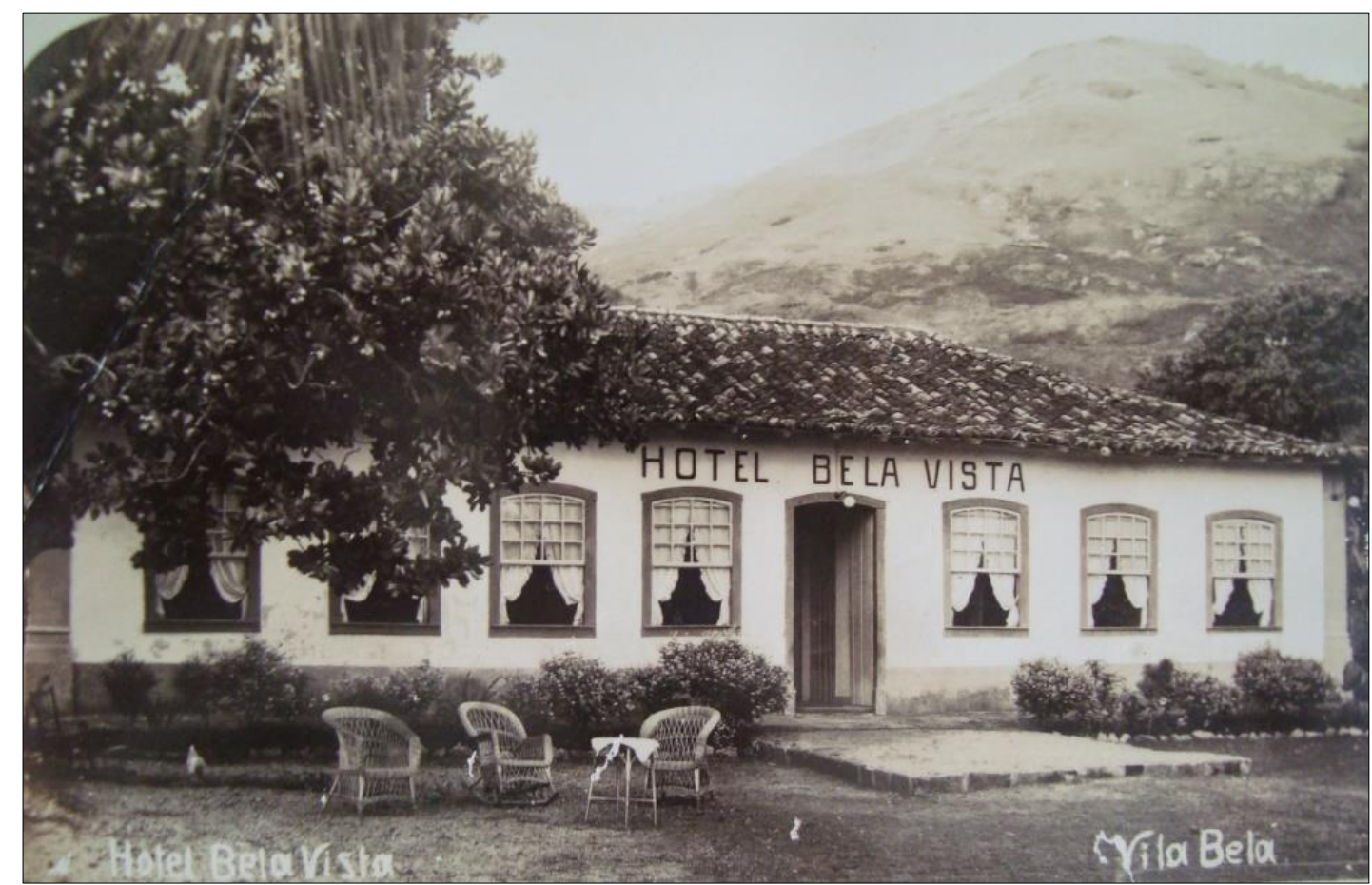

Fonte: Álbuns de fotografias de Luiz Damasco Penna. Acervo particular de Luiz Alberto Penna

$\mathrm{Na}$ ação de visita às escolas, inspetores e delegados de ensino atuavam como "peregrinos" da administração educacional tencionando os sentidos múltiplos implicados no controle, na orientação e na fiscalização do ensino. As fotografias reunidas por Luiz Damasco Penna põem em questão as vicissitudes do trabalho desses profissionais da educação e nos convidam a interrogar, de diferente perspectiva, o exercício dos agentes da inspeção escolar.

\subsection{Acompanhamento dos trabalhos escolares}

No trabalho de inspeção do ensino, inspetores e delegados deveriam observar os mais diversos aspectos da rede escolar: as condições dos prédios, os materiais, o cumprimento dos programas, os métodos de ensino, a escrituração escolar, o desempenho de professores e alunos. As inúmeras fotografias de escolas reunidas por Luiz Damasco Penna revelam representações variadas desse cotidiano escolar, diverso e multifacetado.

As fotografias de escola presentes nos álbuns de Luiz Damasco Penna reproduzem os formatos dominantes de fotografias do universo escolar difundidos no país até meados do século XX: fachadas de prédios escolares, retratos de turmas de alunos e de grupos de professores, quadros de formatura, solenidades e eventos, práticas escolares, entre outros.

Para este estudo selecionamos os tipos de imagens mais recorrentes nos álbuns do professor Penna que explicitam essa dimensão da atividade de inspeção de acompanhamento da vida escolar. Iniciamos pelos prédios escolares, preocupação permanente dos inspetores e delegados de ensino que deveriam verificar, atestar e informar às autoridades centrais do ensino as condições dessas instalações.

As figuras 9 e 10 são denotativas da diversidade dos estabelecimentos de ensino primário na região de Santos. Vale mencionar que fotografias de prédios escolares foram muito utilizadas no início do século XX no Estado de São Paulo como cartão-postal para propagar a ação do Poder Público no campo da educação, dando visibilidade à arquitetura, especialmente de grupos escolares e escolas normais construídos pelo Estado. 
Figura 9 - Fachadas de prédios de grupos escolares da região escolar de Santos. ${ }^{15}$
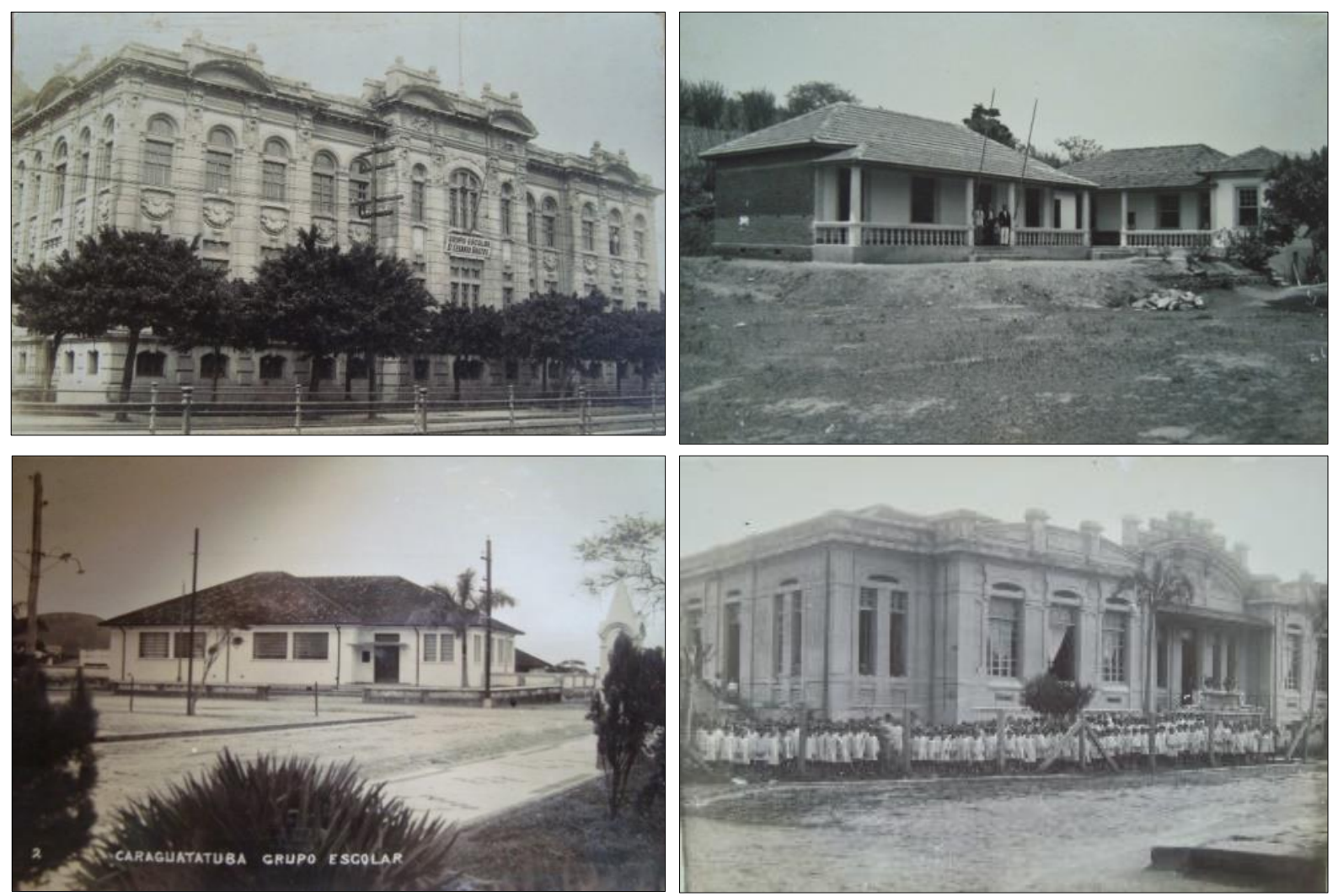

Fonte: Álbuns de fotografias de Luiz Damasco Penna. Acervo particular de Luiz Alberto Penna.

Não obstante, essa monumental arquitetura escolar restringiu-se a algumas escolas e localidades. Como observou Souza (2009), a política de construções escolares não acompanhou a rápida expansão do ensino primário no Estado de São Paulo. Consequentemente, boa parte das unidades escolares funcionavam em edificações simples e em casas alugadas e adaptadas. O problema era ainda maior nas áreas rurais onde a maioria das escolas funcionava em casas cedidas pelos fazendeiros em condições precárias de instalação, muitas em casas de tábuas, barracos e casebres. ${ }^{16}$ Compreende-se, dessa maneira, porque os prédios escolares consistiam em um dos maiores problemas do ensino público.

No relatório da Delegacia de Ensino de Santos de 1935, o delegado Luiz Damasco Penna apresentou uma descrição minuciosa das condições físicas de cada um dos prédios escolares do litoral paulista. De acordo com Penna, dos 24 grupos escolares existentes na região de Santos somente 9 (nove) funcionavam em prédios próprios enquanto $12 \mathrm{em}$ edifícios particulares em péssimas condições. A situação era ainda mais grave nas escolas rurais. Segundo Penna, apenas $40 \%$ das 136 escolas rurais da região encontravam-se em boas condições de infraestrutura enquanto os $60 \%$ restantes podiam ser classificadas como em condições regulares e péssimas. Por isso, o delegado reiterava sua posição:

15 Da esquerda para a direita: GE Dr. Cesário Bastos (1933) - onde funcionou a sede da Delegacia de Ensino de Santos -, GE de Alecrim, GE de Caraguatatuba (cartão postal) e GE de Iguape (1933).

${ }^{16}$ Referindo-se aos dados estatísticos do Estado de São Paulo, em relação ao ano de 1944, Souza afirma: "Numa população absoluta de 7.890.200 habitantes, o contingente de crianças em idade escolar era igual a 1.190.722, das quais 606.553 estavam matriculadas em escolas primárias. Os percentuais de matrícula da população urbana em relação à população rural continuavam muito superiores. Enquanto a matrícula atingia a média de 88,1\% nas zonas urbanas do interior paulista, nas zonas rurais abrangia apenas, 30,4 da população. (2009, p. 124). 
Temos por convicção segura que enquanto não se cuidar de installar soffrivelmente o professor rural, baldeadas serão quaes quer tentativas no sentido, não apenas de dar determinada orientação ao ensino rural, mas de assegurar o funccionamento conveniente de qualquer typo de escola. Seria obra de incalculável alcance convencer os prefeitos municipaes de que mais valeria construir uma casa boa por ano, do que estarem a nomear, como professores municipaes, leigos semi analphabetos a $100 \$ 000$ e até a 50\$000 mensaes. (RELATÓRIO DA DELEGACIA DE SANTOS, 1935, p. 12).

O delegado Penna afirmou também, que iria em breve enviar um álbum fotográfico com todos os prédios escolares: "Durante o corrente anno organizaremos um álbum com photografia de todos os prédios escolares, para ser enviado a Vossa Senhoria". (RELATÓRIO DA DELEGACIA DE SANTOS, 1935, p. 13). Dessa maneira, o delegado pretendia atender à solicitação da Diretoria do Ensino que desejava conhecer, atestar e registrar as condições dos prédios em que funcionavam as escolas públicas do Estado.

Figura 10- Fachadas de escolas rurais da região escolar de Santos (Escola Isolada Rural de Piratininga, 1930, e Escola Mista Típica Rural da Enseada, São Sebastião, 1950).

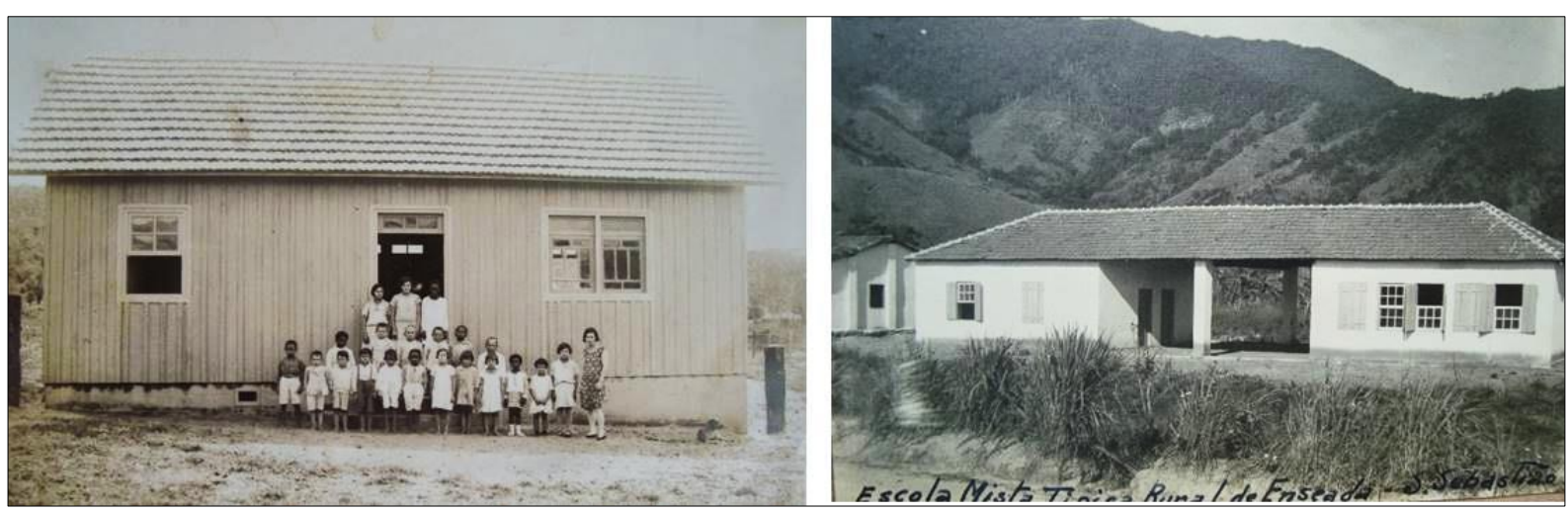

Fonte: Álbuns de fotografias de Luiz Damasco Penna. Acervo particular de Luiz Alberto Penna.

Na Figura 10, sobressaí, no entanto, a modernização das construções escolares no campo fruto de políticas do governo federal e estadual nas décadas de 1940 e 1950. Trata-se de uma escola típica rural. A imagem salienta uma casa bem construída e de aparência confortável com uma parte destinada à residência do professor e outra para as atividades escolares. ${ }^{17}$

Além de verificar as condições dos prédios escolares e relatá-las às autoridades educacionais, outra atividade importante do serviço de inspeção consistia na coordenação das reuniões pedagógicas e na orientação pedagógica dos professores assistindo às aulas e ministrando aulas modelo quando em visita às escolas. A sala de aula, pouco retratada nas fotografias escolares aparece em algumas imagens nos álbuns de Luiz Damasco Penna evidenciando a representação simbólica dessa unidade espacial e pedagógica que enlaça sentidos identitários, articulando professores e alunos. A figura 11 dá visibilidade a uma cena

17 Nas décadas de 1940 e 1950 foi instituído no estado de São Paulo o denominado "ensino típico rural" compreendendo diferentes tipos de escolas primárias (granjas escolares, grupos escolares rurais e escolas típicas rurais) com programas de ensino e orientação pedagógica voltada para as zonas rurais. As escolas típicas rurais consistiram em escolas isoladas localizadas no campo diferenciadas das demais escolas isoladas "pela orientação dada ao ensino incluída no programa, a exigência de prédio com instalações adequadas para funcionamento da escola incluindo residência para o professor, além de terreno para desenvolvimento de atividades agrícolas". (SOUZA; MORAES, 2015). Sobre o ensino típico rural no estado de São Paulo, ver: Moraes, 2014. 
típica de uma visita do inspetor a uma sala de aula de um grupo escolar. Todos os alunos perfilados e atentos assistem à aula. Os quadros estão cheios de conteúdos de matemática e língua portuguesa. De um lado, a professora toma lição de cálculo de um aluno no quadro negro, enquanto no outro lado da sala o inspetor observa uma aluna ordenando sentenças. ${ }^{18}$ Dessa maneira, a imagem reforça a dimensão pedagógica do exercício da inspeção, dimensão corroborada nos discursos das autoridades do ensino, mas difícil de execução dado o excesso de atribuições burocráticas e administrativas atribuídas aos inspetores e delegados de ensino (LIGEIRO, 2014). No relatório da Delegacia de Santos de 1943, o delegado Luiz Damasco Penna informou que cada inspetor havia ministrado, em média, 470 aulas modelo no ano e que eles assistiram, em média, 505 aulas. (RELATÓRIO DA DELEGACIA DE SANTOS, 1943).

Figura 11 - Sala de aula do $1^{\circ}$ ano misto, do Grupo Escolar de Raposa, 1938.

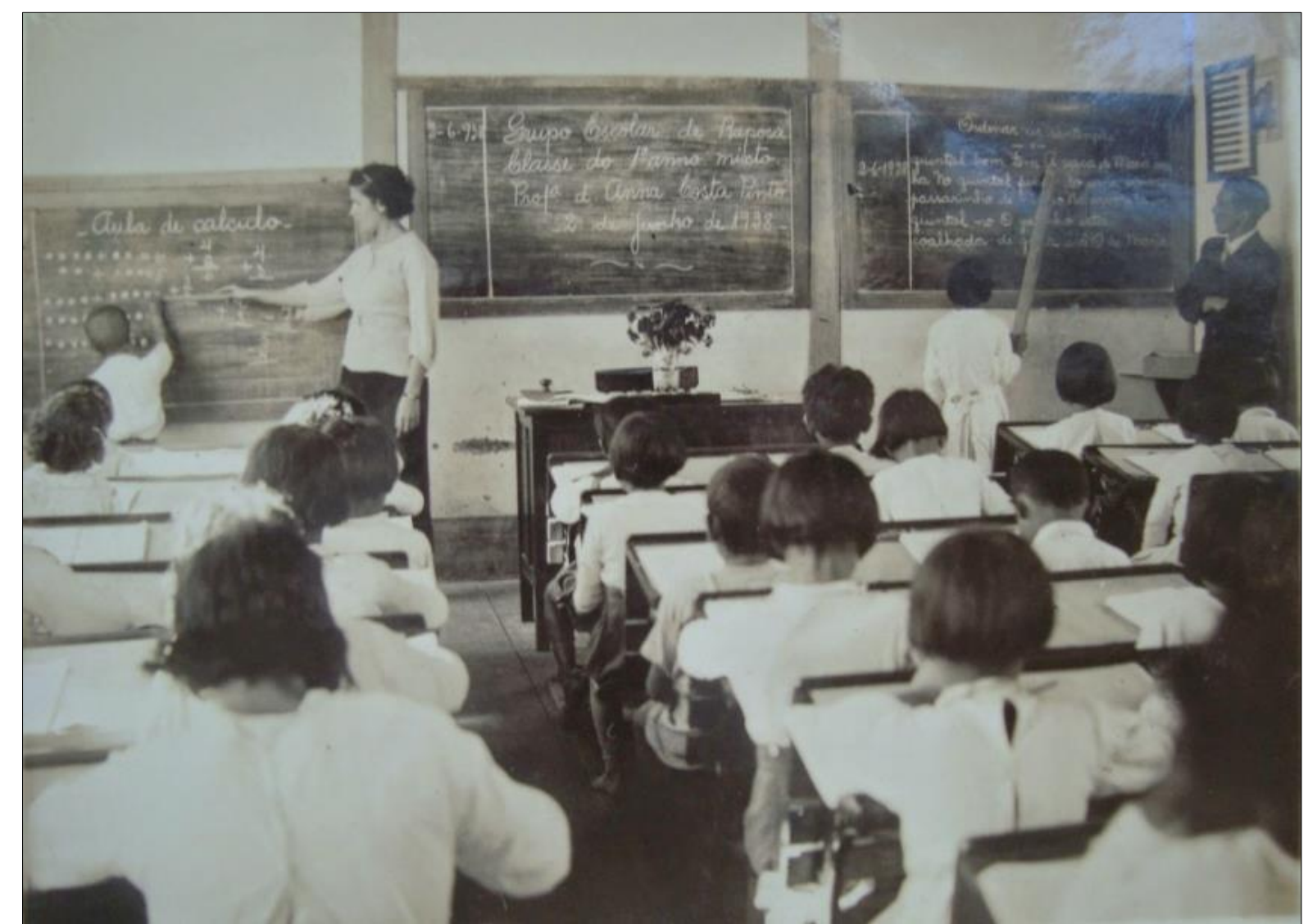

Fonte: Álbuns de fotografias de Luiz Damasco Penna. Acervo particular de Luiz Alberto Penna.

Inspetores e delegados em suas visitas às escolas acompanhavam também as práticas escolares, especialmente o funcionamento das instituições auxiliares da escola consideradas instrumentos importantes da renovação didática. Na figura 12, as imagens retratam algumas dessas instituições como a sopa escolar, o gabinete dentário e o ensino agrícola. Cabia aos inspetores e delegados de ensino incentivar os professores e diretores de grupos escolares a implantarem práticas de renovação pedagógica. Fotografias das atividades inovadoras adotadas nas escolas buscavam atestar os avanços alcançados, frutos, em certa medida, da atuação vigilante e diligente do serviço de inspeção.

\footnotetext{
${ }^{18}$ No quadro negro central da sala de aula está registrado o cabeçalho do dia: "Grupo Escolar de Raposa. Classe do $1^{\circ}$ anno mixto. Profa. d. Anna Costa Pinto. 2 de Junho de 1938”.
} 
Figura 12 - Instituições auxiliares da escola.

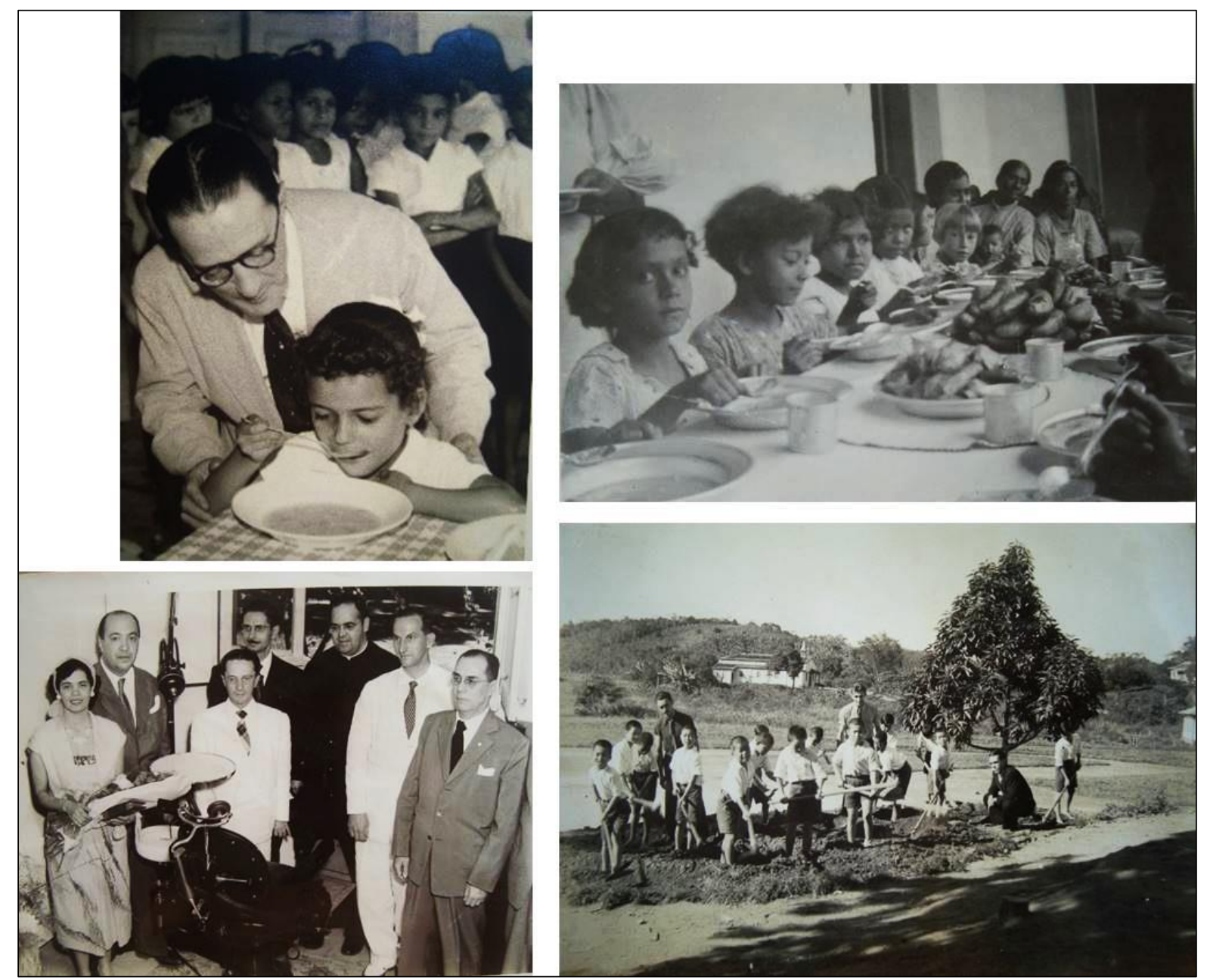

Fonte: Álbuns de fotografias de Luiz Damasco Penna. Acervo particular de Luiz Alberto Penna.

Os álbuns de fotografias de Luiz Damasco Penna contêm inúmeras representações da cultura escolar, da fachada das escolas às salas de aula, das instituições auxiliares à fragmentos da inovação pedagógica. Essas imagens provavelmente produzidas para testemunhar a situação da educação primária no litoral paulista consagraram uma memória da educação pública. No entanto, na esteira da observação de Ciro Flamarion Cardoso e Ana Maria Mauad (1997, p. 405) cabe ao historiador desvelar o que não foi revelado pelo olhar fotográfico, desafio que implica "desvendar uma intrincada rede de significações, cujos elementos - homens e signos - interagem dialeticamente na composição da realidade". No caso específico deste texto, cabe apontar o lugar social e educacional ocupado pelos inspetores e delegados na construção da cultura escolar.

\subsection{Participação em eventos e solenidades}

Parte considerável do trabalho do delegado de ensino consistia em participar de festas, eventos e solenidades representando o Poder Público e contribuindo para o abrilhantamento da atividade. Em todas essas atividades ressalta-se a representação investida no cargo dos inspetores e delegados de ensino. Termo polissêmico vale retermos aqui a explicação de Roger Chartier (2011) sobre a dupla definição antiga do termo representação, isto é, ela tanto "remete à ideia e à memória os objetos ausentes", como constitui a demonstração de uma presença. Para a análise da atividade inspetora vale reter o sentido político e jurídico do termo 
explicado pelo autor: "aquele que representa uma função pública, representa uma pessoa ausente que lá deveria estar", e "aqueles que são chamados a uma sucessão estando no lugar da pessoa de quem têm o direito" (CHARTIER, 2011, p. 17) e ainda, a representação como exibição de algo, significando autoridade, dignidade, caráter.

Dessa perspectiva, podemos interpretar a dimensão simbólica da ação inspetora que se investe de autoridade e se constrói a partir dela. Essa dupla dimensão é perceptível na participação dos inspetores e delegados de ensino nos eventos e solenidades educacionais. Vale ressaltar, por exemplo, as práticas de formação em serviço do magistério primário e de auto formação dos profissionais da inspeção escolar.

Nos álbuns de fotografias de Luiz Damasco Penna encontramos 68 imagens relacionadas à participação desse educador em eventos e solenidades diversas: inauguração de escolas, festas e comemorações cívicas, visita de autoridades às escolas, formaturas e encerramento do ano letivo, congressos de educadores.

A partir de 1930, intensificou-se na rede pública de ensino paulista o oferecimento de cursos de atualização e de férias para o magistério primário com diferentes finalidades formativas.

A presença do inspetor e/ ou do delegado de ensino nessas atividades conferia-lhes maior legitimidade. A figura 13 evidencia uma dessas atividades - um curso promovido pelo programa de educação sanitária no qual o prof. Penna esteve presente e cuja recordação foi perpetuada na fotografia.

Figura 13- Curso contra malária dentro do programa de educação sanitária desenvolvido no litoral norte com professores e diretores em 1936.

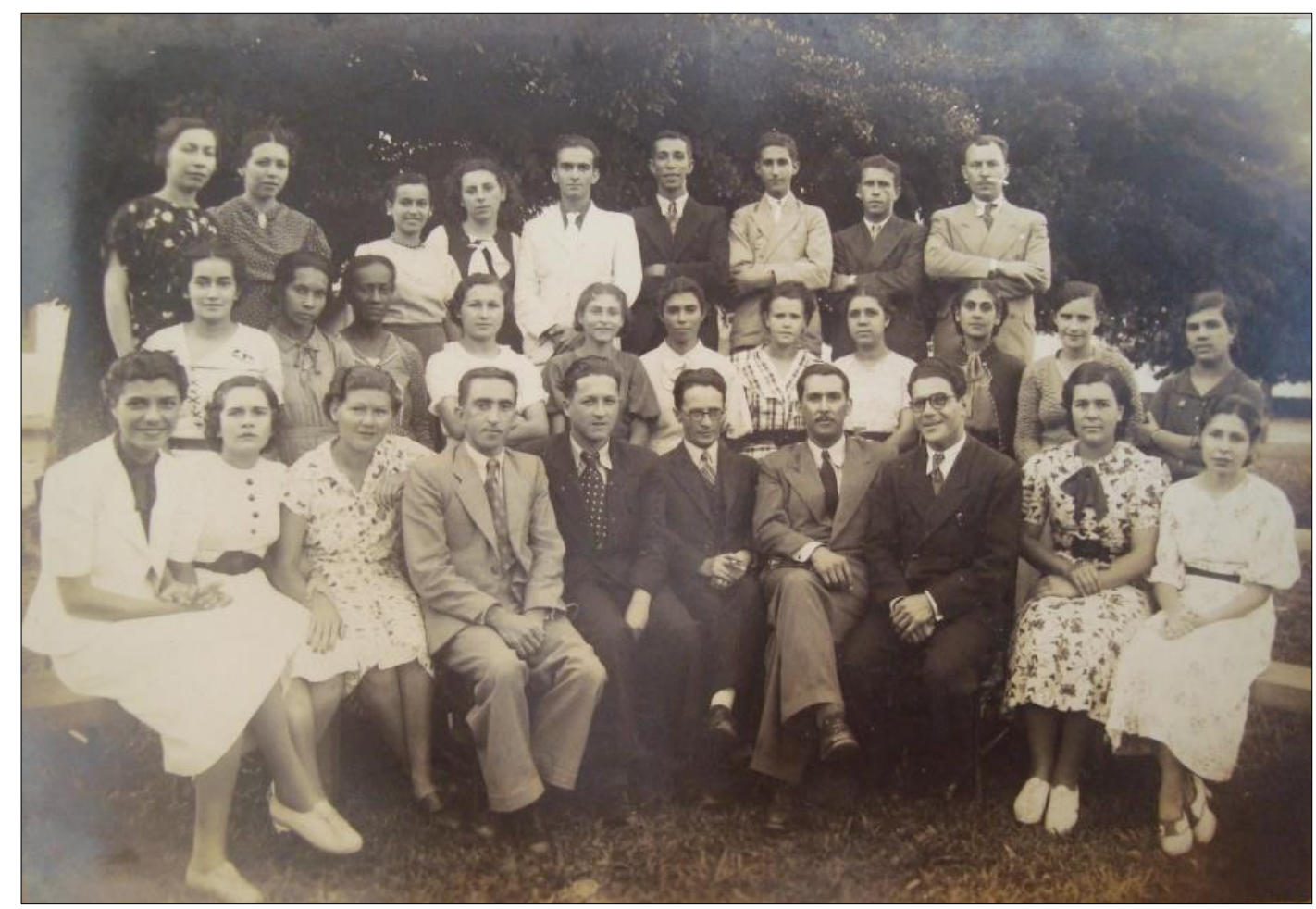

Fonte: Álbuns de fotografias de Luiz Damasco Penna. Acervo particular de Luiz Alberto Penna.

Entre as décadas de 1930 e 1960, a orientação e a fiscalização do ensino passou a adotar novas estratégias de normatização e modelização do campo educacional articulando dimensões pedagógicas e administrativas. Exemplos dessas práticas constituíram as reuniões 
mensais de professores de escolas isoladas e de grupos escolares com diretores e inspetores, as reuniões anuais dos inspetores e diretores com o delegado regional e reuniões dos delegados regionais com as autoridades da Secretaria de Estado da Educação. Essas reuniões de trabalho propiciavam a circulação de normas e diretrizes como também a discussão de problemas educacionais e encaminhamento de soluções em diferentes âmbitos de atuação.

Na mesma direção, a participação das autoridades do ensino primário em congressos educacionais passou a ser incentivada pela Secretaria de Estado da Educação como meio de participação no debate educacional e de aprimoramento profissional. Na figura 14 observamos duas fotografias que retratam a participação do delegado Penna em eventos dessa natureza: um congresso realizado em Porto Alegre em 1958 e no IV Congresso Nacional de Professores Primários realizado em Recife, em 1960.

Figura 14 - Congressos e eventos educacionais ${ }^{19}$
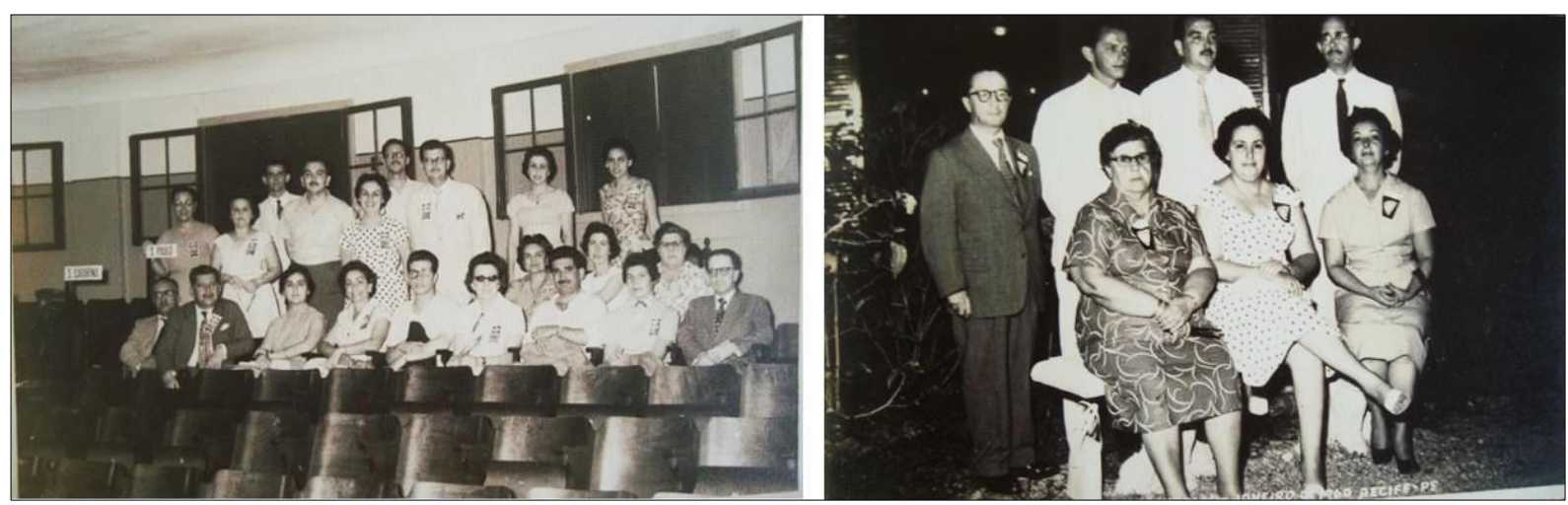

Fonte: Álbuns de fotografias de Luiz Damasco Penna. Acervo particular de Luiz Alberto Penna.

Portanto, vários sentidos estavam implicados nas atividades de representação desenvolvidas por inspetores e delegados de ensino. Alguns deles podemos observar nos próprios relatos de Luiz Damasco Penna: "Tive a honra de acompanhar Sua Excelência o Senhor Interventor Federal na excursão que realizou de 8 a 11 de junho a municípios do litoral sul, proferindo, a mandado de Sua Excelência, oração na solenidade do lançamento da pedra fundamental do G.E. de Registro". (RELATÓRIO DA DELEGACIA DE SANTOS, 1940, p. 3-4).

Referia-se o prof. Penna à visita do interventor Ademar de Barros à região escolar de Santos em junho de 1940. Momento de grande solenidade, a visita do representante máximo do poder político no Estado de São Paulo ao litoral envolveu inauguração de escolas, desfiles, e outras atividades registradas em fotografias como a figura 15 na qual professores e autoridades locais de Cananéia acompanham o interventor enquanto alunos do grupo escolar saúdam a comitiva empunhando bandeiras.

${ }^{19}$ A primeira imagem refere-se ao Congresso em Porto Alegre, 1958. A segunda, ao IV Congresso Nacional de Professores Primários realizado em Janeiro de 1960, em Recife. (Da esquerda para a direita: Luiz Damasco Penna, Antônio Ávila, Douglas Escobar Bueno, (sic) Amaro Cruz. Sentadas: Henriqueta, Inalda Lúcia Lins de Lima e Alda Marques Gonçalves. 
Figura 15- Visita do interventor Adhemar de Barros ao GE de Cananéia, em junho de 1940.

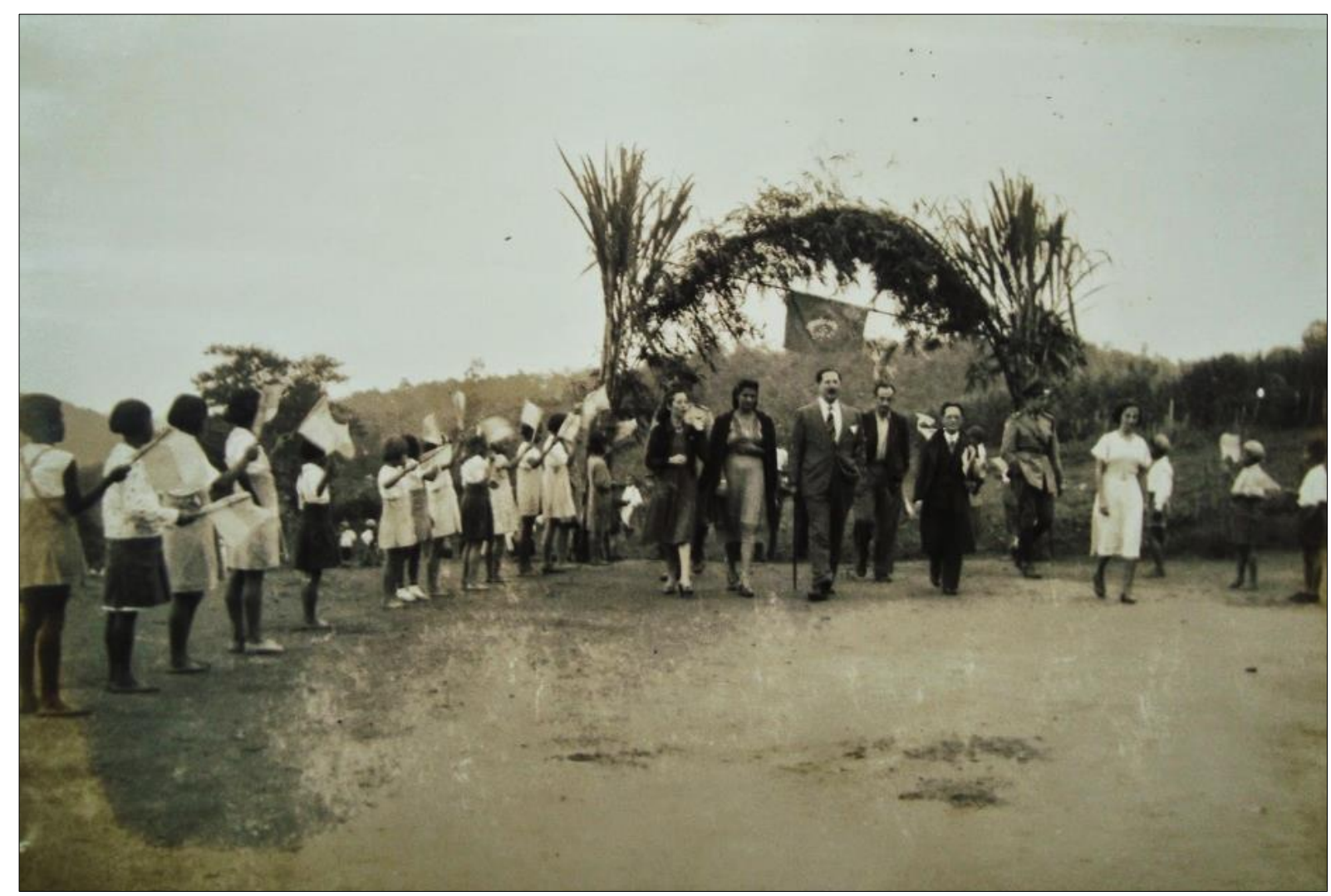

Fonte: Álbum de fotografia de Luiz Damasco Penna. Acervo particular de Luiz Alberto Penna.

Ainda no relatório da Delegacia de Santos de 1940, o delegado Penna prossegue informando as atividades de representação por ele desenvolvidas e o seu significado pessoal e profissional:

Mereci ainda a distinção de representar o Snr. Prof. Dario de Moura e, depois, Vossa Senhoria, em diversas solenidades efetuadas nesta cidade e compareci pessoalmente, ou me fiz representar, em todas as festas e solenidades para as quais a delegacia recebeu convite. Paraninfei a turma de diplomados no Instituto D. Escolástica Rosa [Santos], o que relato porque a distinção foi sem dúvida endereçada já ao professorado que dirijo, já ao Departamento de que tenho a honra de ser delegado. (RELATÓRIO DA DELEGACIA DE SANTOS, 1940, p. 4).

Pode-se, por conseguinte, afirmar que era na condição de autoridade do ensino que a presença do delegado regional expressava toda a sua dimensão simbólica como expressão da autoridade administrativa. Especialmente nas festas e comemorações cívicas realizadas nas escolas, tal participação não somente abrilhantava a solenidade como reafirmava a relevância sócio cultural e pedagógica da celebração. Como assinalou Souza (1998), na transição do século XIX para o século XX, os republicanos paulistas instituíram no aparelho de instrução pública várias práticas simbólicas de expressão do imaginário sociopolítico da República. "Festas, exposições escolares, desfiles dos batalhões infantis, exames e comemorações cívicas constituíram momentos especiais na vida da escola pelos quais ela ganhava ainda maior visibilidade social e reforçava sentidos culturais compartilhados”. (SOUZA, 1998, P. 241) 
Como fenômeno cultural, social e político, a festa promove laços de sociabilidade constituindo-se, também, como palco de conflitos e tensões sociais. Como tem assinalado vários autores (OZOUF, 1988, LEONEL, 2009) a festa rompe com a rotina e configura um tempo consagrado. As festas cívicas, por sua vez, têm a finalidade de perpetuar a memória nacional. $\mathrm{Na}$ escola as festas e comemorações cívicas têm uma inequívoca finalidade pedagógica. Elas reafirmam laços de sociabilidade ao mesmo tempo em que reafirmam práticas culturais. Além disso, ratificam valores cívico-patrióticos contribuindo para reforçar a memória histórica por meio do festejo do calendário nacional.

Nos álbuns de Luiz Damasco Penna há inúmeras fotos retratando esses momentos rituais do calendário escolar: o dia da Pátria, desfiles em comemoração ao aniversário da escola e da cidade, o dia dos animais e da árvore, a festa de encerramento do ano letivo.

Em todas essas cerimônias especiais, inspetores e delegados eram instados a comparecer reforçando, pela autoridade legítima a eles conferida, a chancela do Estado e a relevância sociocultural e educativa da comemoração e da escola.

Nas figuras 16 e 17, as imagens retratam a diversidade das celebrações escolares realizadas na região de Santos. Na figura 16, as duas imagens da esquerda ressaltam a apresentação teatral de um grupo de alunos em 1952 e as duas imagens à direita põem em relevo a participação dos alunos uniformizados e enfileirados, participando de solenidades como atores e observadores. A figura 17 dá visibilidade aos desfiles cívicos, prática educativa muito disseminada nas escolas públicas primárias paulistas e brasileiras no século XX.

Figura 16- Festas escolares na região escolar de $\operatorname{Santos}^{20}$

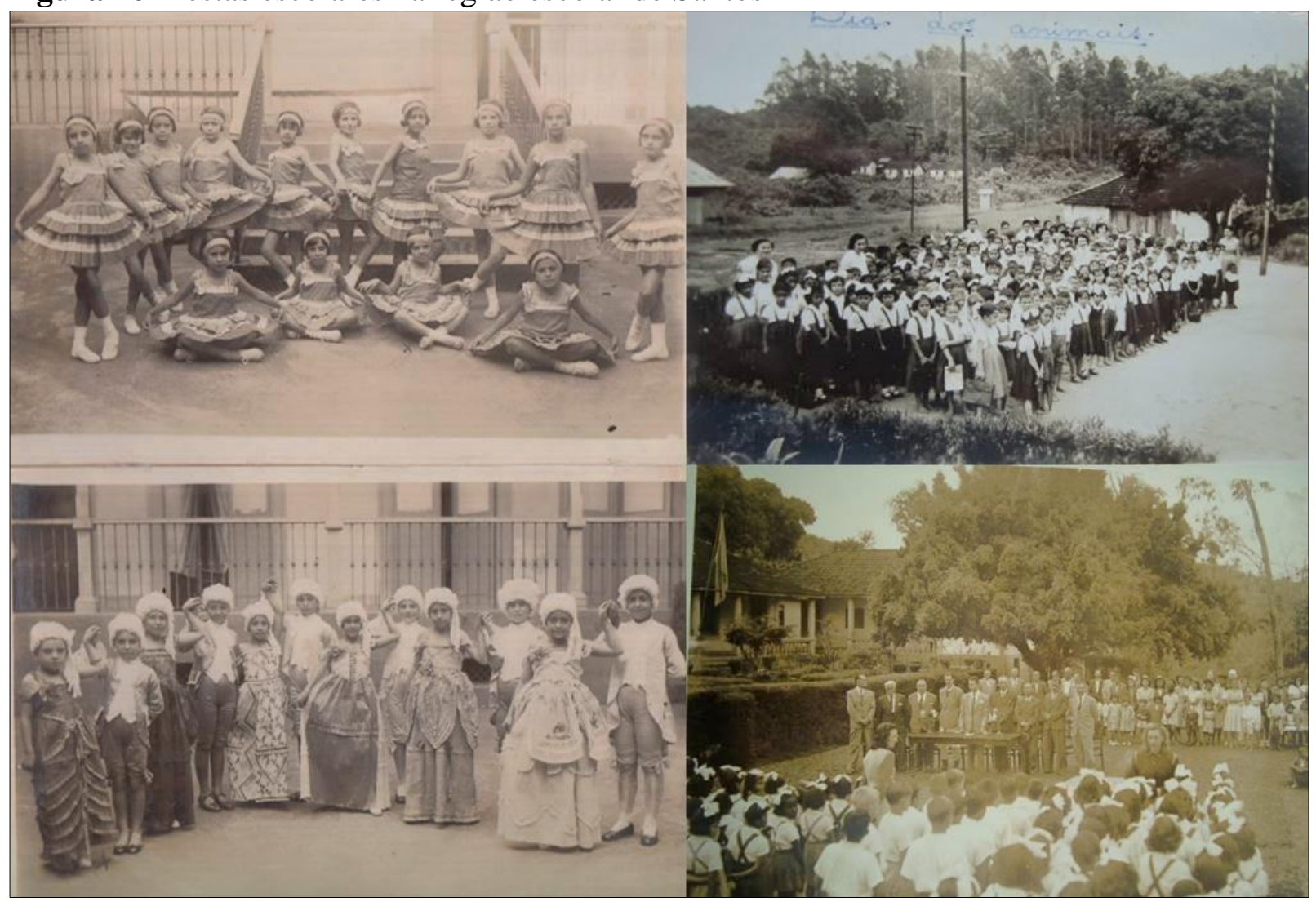

Fonte: Álbuns de fotografias de Luiz Damasco Penna. Acervo particular de Luiz Alberto Penna.

${ }^{20}$ As imagens da direita referem-se à apresentação teatral, 1952. A de cima da direita ao Dia dos animais no GE de Cedro, 1952, e a de baixo à Solenidade no GE Pedro de Toledo (antigo GE Alecrim), 1947 (comemoração cívica no pátio em frente ao prédio da colônia japonesa). 
Figura 17 - Desfiles cívicos - Sete de Setembro

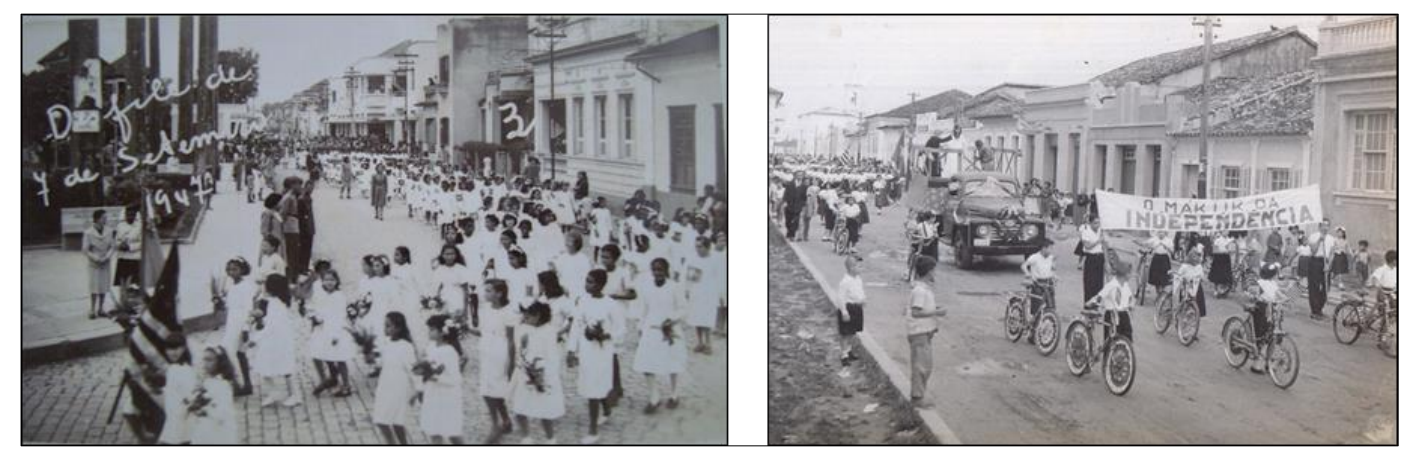

Fonte: Álbuns de fotografias de Luiz Damasco Penna. Acervo particular de Luiz Alberto Penna.

Por último, vale destacar uma dimensão relevante contida nas representações da inspeção escolar: a presença de inspetores e delegados de ensino nas fotos de classe do $4^{\circ}$ ano (com os diplomandos do curso primário) e nos quadros de formatura.

A figura 18 apresenta algumas fotografias desse tipo que se tornaram muito populares e comercializáveis em meados do século XX. A propósito, como salientou Souza (2009, p. 322) acerca desse tipo de fotografias: "Tiradas geralmente no encerramento do ano letivo, coincidem com as solenidades de entrega dos diplomas, certificação do mérito alcançado por bem poucos alunos". O acompanhamento da disciplina, da frequência e do desempenho dos alunos compreendiam parte relevante do trabalho realizado pelos agentes da inspeção escolar. Nas escolas públicas primárias paulistas, as provas finais eram elaboradas pela delegacia de ensino e os exames consistiam em rituais de consagração pública, pois, validavam desempenho e condutas de alunos e professores jogando um papel crucial em um sistema de ensino altamente seletivo. Dessa maneira, a festa de encerramento do ano letivo com a entrega dos diplomas aos concluintes do $4^{\circ}$ ano primário compreendia uma solenidade de grande prestígio e valor simbólico para a comunidade escolar e para a sociedade local.

Figura 18- Quadros de formatura

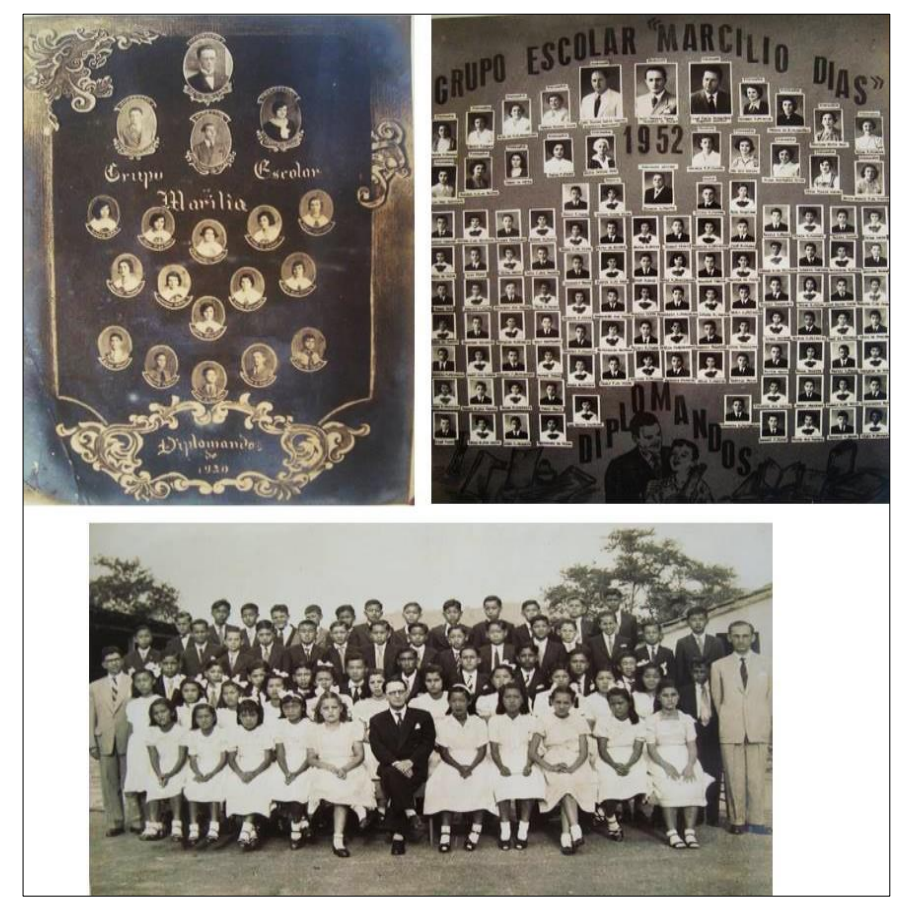

Fonte: Álbuns de fotografias de Luiz Damasco Penna. Acervo particular de Luiz Alberto Penna. 
A representação dessa celebração do mérito escolar registrada em fotografias entrelaçava alunos, professores e autoridades do ensino enaltecendo múltiplos sentidos socioculturais como honra, distinção, sucesso, dedicação, êxito, entre outros.

A análise de Werle (2005) sobre a relação entre os quadros de formatura e a memória institucional merece ser recordada, pois, evidencia mais uma dimensão dessa prática de representação da cultura escolar. Como afirma a autora: "Uma formatura é um importante momento no funcionamento das instituições escolares, destacada referência por comprovar os atos pedagógicos de sucesso processados em seu interior”. (WERLE, 2005, p. 3).

Portanto, trata-se de uma dupla representação: o quadro de formatura como suporte material para ser afixado em local de destaque na escola e como fotografia de recordação escolar. Ainda de acordo com Werle (2005), os quadros de formatura hierarquizam, isto é, eles homogeneízam os alunos em roupas e poses, ao mesmo tempo em que destacam homenageados e figuras ilustres. $\mathrm{Na}$ figura 18 podemos observar essa distribuição hierarquizada da "dimensão institucional de sucesso". Na fotografia do quadro de formatura do Grupo Escolar de Marília, de 1930, sobressaí a foto de Luiz Damasco Penna em primeiro lugar como paraninfo. O mesmo ocorre no quadro de formatura do Grupo Escolar Marcílio Dias, de Guarujá, de 1952, onde, prof. Penna aparece em primeiro plano como delegado do ensino acompanhado também em destaque à esquerda pelo prefeito municipal, João Torres Leite Soares, e à direita por José Paulo Guimarães, inspetor escolar.

Ainda em relação à figura 18 , na foto de classe, nota-se também a centralidade da figura do delegado de ensino, cuja autoridade representa o sentido figurativo do poder do Estado e da administração educacional. Em síntese, pode-se dizer que, nas diversas ações de representar, os agentes da inspeção do ensino contribuíram para a construção de uma memória da educação pública paulista.

\section{Considerações finais}

Como afirmamos inicialmente, os álbuns de fotografias de Luiz Damasco Penna compreendem um inventário iconográfico da cultura escolar primária e sobretudo do litoral paulista. Tal acervo permite múltiplos recortes seriais e diversas leituras, contudo, neste texto optamos por problematizar três dimensões do serviço de inspeção mais reincidentes nas fotografias reunidas por Luiz Damasco Penna: as viagens de visita às escolas, o acompanhamento da rede escolar e a participação dos agentes da inspeção em eventos e solenidades do Estado de São Paulo.

Representação e memória são dimensões constituintes da fotografia. Nos álbuns de Luiz Damasco Penna representações da escola primária e da inspeção escolar estão entrelaçadas. No exercício profissional, inspetores e delegados de ensino acompanhavam diversas atividades, práticas, situações, acontecimentos da vida escolar. As fotografias são recordações individuais, mas também coletivas da comunidade escolar: a escola, a fachada do prédio, a classe, a turma de alunos, o grupo de professores, o quadro de formatura, os desfiles cívicos, as solenidades ...

Como advertem Felizardo e Samain (2007), a fotografia carrega a magia da eternização do momento, suscitando recordações e sentimentos. Certamente, para Luiz Damasco Penna, essas inúmeras fotografias escolares que reuniu e organizou consistiam em 
fragmentos de sua história de vida, lembranças de sua trajetória profissional. No entanto, para o olhar do historiador da educação, elas adquirem novos sentidos, elas se convertem em documentos, representações da vida escolar, vestígios impressionantes e reveladores da cultura da escola. Em relação à inspeção escolar, essas fotografias instigam uma leitura "a contra pelo", isto é, induzem interrogar as representações instituídas sobre o serviço de inspeção atreladas ao controle e ao exercício do poder. Qual o significado da inspeção para os próprios inspetores e delegados de ensino? Qual foi a experiência profissional desses sujeitos educacionais? Qual foi a contribuição desses educadores para a educação pública?

De certa maneira, buscamos neste texto problematizar algumas dessas questões. Os álbuns de fotografias de Luiz Damasco Penna ao mesmo tempo em que ratificam representações ordinárias da escola, põem em discussão as múltiplas faces, recordações e memórias da atuação dos inspetores e delegados de ensino. Nessa reflexão, a fotografia documento / relicário nos convida a ver e pensar diferentemente; por certo, uma aventura inolvidável.

\section{Referências}

ABDALA, Rachel Duarte. Fotografias escolares: práticas do olhar e representações sociais nos álbuns fotográficos da Escola Caetano de Campos (1895 - 1966). São Paulo, 314f. Tese (Doutorado em Educação) - Universidade de São Paulo, São Paulo, 2013. https://doi.org/10.11606/t.48.2013.tde-04112013-113939

ALVES, Edson Rossetti. Análise de fotografias do álbum de Luiz Damasco Penna. In: XXVIII Simpósio Nacional de História, 2015, Florianópolis-SC.

ANDRADE, Ana Maria Mauad de Sousa. Sob o signo da imagem. Niterói, 260 f. Dissertação (Mestrado em História) - Universidade Federal Fluminense, Niterói, 1990.

BARROS, Mikitta Moraes. A autoridade e a hierarquia nas organizações escolares. São Paulo: Emprêsa Gráfica da "Revista dos Tribunais", 1938.

BENCOSTTA, Marcus Levy. Memória e Cultura Escolar: a imagem fotográfica no estudo da escola primária de Curitiba. História (São Paulo) v.30, n.1, p. 397-411, jan/jun 2011. https://doi.org/10.1590/s0101-90742011000100019

CARDOSO, Ciro Flamarion; MAUAD, Ana Maria. História e Imagens: os exemplos da fotografia e do cinema. In: CARDOSO, Ciro Flamarion; VAINFAS, Ronaldo. Domínios da História: ensaios de teoria e metodologia. Rio de Janeiro: Elsevier, 1997.

CELESTE FILHO, Macioniro. Os relatórios das Delegacias Regionais de Ensino do Estado de São Paulo como fonte de pesquisa para a História da Educação - décadas de 1930 e 1940. Revista Brasileira de História da Educação, v. 12, p. 71-111, 2012.

CHARTIER, Roger. Defesa e ilustração da noção de representação. Fronteiras, DouradosMS, v. 13, n. 24, p. 15-29, jul./ de. 2011, pp. 15-29.

DIEGUES, Antonio Carlos. O Vale do Ribeira e Litoral de São Paulo: meio-ambiente, história e população. CENPEC, março 2007. 
FELIZARDO, Adair; SAMAIN, Etienne. A fotografia como objeto e recurso da memória. Discursos fotográficos, Londrina-PR, v. 3, n. 3, p. 205-220, 2007. https://doi.org/10.5433/1984$\underline{7939.2007 v 3 n 3 p 205}$

GONÇALVES, Rogério Bessa. O sincretismo de culturas sob a ótica da arquitetura. Anais do Museu Paulista, São Paulo, v.16, n.1, p.11-46, jan.- jun. de 2008. https://doi.org/10.1590/s0101$\underline{47142008000100002}$

JOLI, Martine. Introdução a análise da imagem. 14.ed. Campinas: Papirus, 2012.

KOSSOY, Boris. A fotografia como fonte histórica: introdução à pesquisa e interpretação das imagens do passado. São Paulo: Museus da Indústria, Comércio e Tecnologia, 1980.

KOSSOY, Boris. Fotografia \& História. 2 ed. São Paulo: Ateliê Editorial, 2001.

KOSSOY, Boris. Fotografia e memória: reconstituição por meio da fotografia. In: SAMAIN, E. (org.). O fotográfico. 3 ed. São Paulo: Editora Hucitec / Editora SENAC, São Paulo, 2005, p. 39-45.

LE GOFF, J. História e memória. Campinas - SP: Editora da Unicamp, 1994.

LEITE, Mirian Moreira. Retratos de família. São Paulo: Editora Universidade de São Paulo, 1993.

LIGEIRO, Dulcinéia Conceição. A inspeção escolar no estado de São Paulo: análise de termos de visitas (1922 - 1966). 117 f. Dissertação (Mestrado em Educação) - Centro Universitário Moura Lacerda, Ribeirão preto, 2014.

LIMA, Edson Prestes Santos. História, memória e educação no olhar "photographico" de Guilherme Gluck (Lapa, 1920 - 1953). Curitiba, 305f. Tese (Doutorado em Educação) Universidade Federal do Paraná, Curitiba, 2015.

MARTELLI, Anita Favaro. Inspeção escolar: contribuição para seu estudo em São Paulo. São Paulo, 1972, 185 f. Tese (Doutorado em Educação), Faculdade de Educação, Universidade de São Paulo, São Paulo, 1972.

MITRULIS, Eleny. “Os últimos baluartes”. Uma contribuição ao estudo da Escola Primária: as práticas de Inspeção Escolar e de Supervisão Pedagógica. São Paulo, 214 f. Tese (Doutorado em Educação), Universidade de São Paulo, São Paulo, 1993.

MORAES, Agnes Iara Domingos. Ensino primário tipicamente rural no Estado de São Paulo: um estudo sobre as Granjas Escolares, os Grupos Escolares Rurais e as Escolas Típicas Rurais (1933-1968). São Paulo: Cultura Acadêmica, 2014.

OZOUF, Mona. A festa: sob a Revolução Francesa. In: LE GOFF, Jacques; NORA, Pierre. História: novos objetos. $3^{\text {a }}$ ed. Rio de Janeiro: Francisco Alves, 1988.

PASQUARELLI, Silvio Luiz Santiago. A presença de Luiz Damasco Penna na Delegacia Regional de Santos do Estado de São Paulo (1932 - 1957). Santos, 149 f. Dissertação (Mestrado em Educação) - Universidade Católica de Santos, Santos, 2012. 
PAULO, Marco Antonio R.; WARDE, Mirian Jorge. A instalação do serviço de inspeção escolar na província de São Paulo (1835 - 1887). Cadernos de História da Educação, v. 12, n. 1, Uberlândia, p. 253 - 275, jan./ jun. 2013.

PEREIRA, Maria Apparecida Franco. Assistência ao Litoral de Anchieta e a experiência de educação de líderes femininas (1939-1942). In: WERLE, Flávia Obino Corrêa (org.). Educação Rural: práticas civilizatórias e institucionalização da formação de professores. São Leopoldo: Oikos; Brasília: Liber Livro, 2010. p.185-211.

PEREIRA, Maria Apparecida Franco. Radiografia de la educación rural paulista (1936). In: Lúcia Lionetti; Alicia Civera; Flávia Obino Corrêa Werle. (Orgs.). Sujetos, comunidades rurales y culturas escolares. Rosario: Prohistoria, 2013, v. 1, p. 170-191.

POSSAMAI, Zita Rosane. Fotografia, história e vistas urbanas. História, São Paulo, 27, n. 2, p. 253-277, 2008. https://doi.org/10.1590/s0101-90742008000200012

RELATÓRIO DA DELEGACIA REGIONAL DE SANTOS, 1935. Disponível em: <http://www.arquivoestado.sp.gov.br/educacao/instrucao.php>. Acesso em 24 junho 2016.

RELATÓRIO DA DELEGACIA REGIONAL DE SANTOS, 1936. Disponível em: <http://200.144.6.120/uploads/acervo/periodicos/relatorios_educacao/RDRSA1936.pdf >. Acesso em 14 abril 2017.

RELATÓRIO DA DELEGACIA REGIONAL DE SANTOS, 1938. Disponível em: <http://www.arquivoestado.sp.gov.br/educacao/instrucao.php>. Acesso em 17 março 2017.

RELATÓRIO DA DELEGACIA REGIONAL DE SANTOS, 1940. Disponível em: <http://www.arquivoestado.sp.gov.br/educacao/instrucao.php>. Acesso em 15 março 2017.

RELATÓRIO DA DELEGACIA REGIONAL DE SANTOS, 1943. Disponível em: <http://www.arquivoestado.sp.gov.br/educacao/instrucao.php >. Acesso em 17 março 2017.

SAMAIN, Etienne. (org.). O fotográfico. 3 ed. São Paulo: Editora Hucitec / Editora SENAC, São Paulo, 2005.

SÃO PAULO (Estado). Lei n. 1.750, de 8 de dezembro de 1920. Reforma a Instrucção Pública. ALESP. Disponível em: <https://www.al.sp.gov.br/norma/?id=65983>. Acesso em 21 ago 2017.

SÃO PAULO (Estado). Decreto n. 3.858, de 11 de junho de 1925. Reforma a Instrução Pública. ALESP. Disponível em: <https://www.al.sp.gov.br/norma/?id=133332>. Acesso em 17 ago 2017.

SÃO PAULO. Decreto n. 5.884, de 21 de abril de 1933. Institui o Código de Educação do Estado de São Paulo. Secretaria da Educação e da Saúde. São Paulo: Imprensa Oficial do Estado, 1933.

SÃO PAULO (Estado). Decreto n. 17.698, de 26 de novembro de 1947. Aprova a Consolidação mandada elaborar pelo decreto n. 17.211, de 13 de maio de 1947. Coleção das Leis e Decretos do Estado de São Paulo de 1947. Tomo LVIII. $4^{\circ}$ trimestre. $1^{\circ}$ volume. São Paulo: Imprensa Oficial do Estado, 1948. 
SÃO PAULO. Annuário do Ensino do Estado de São Paulo: 1935-1936. Publicação organizada pela Directoria Geral da Instrucção Pública por ordem do governo do Estado, São Paulo: Tip. Siqueira, [1937].

SÃO PAULO. Annuário do Ensino do Estado de São Paulo: 1936-1937. Publicação organizada pela Directoria Geral da Instrucção Pública por ordem do governo do Estado, São Paulo: Tip. Siqueira, [1938].

SÃO PAULO. LEI COMPLEMENTAR No 114, DE 13 DE NOVEMBRO DE 1974. Institui o Estatuto do Magistério Público de $1 .^{\circ}$ e $2 .^{\circ}$ graus do Estado e dá providências correlatas. Disponível em: <https://www.al.sp.gov.br/norma/?id=29056>. Acesso em 30 setembro 2017.

SILVA, Denise Guilherme. "Ilhas de saber": prescrições e práticas das escolas isoladas do estado de São Paulo (1933-1943). São Paulo, 138f. Dissertação (Mestrado em Educação: História, Política, Sociedade) - Pontifícia Universidade Católica de São Paulo, São Paulo, 2004.

SILVA, Rafael da Silva; DEMARTINI, Zeila de B. F. Eiji Matsumura: contribuição biográfica para a História da Educação no Vale do Ribeira. Cadernos de Educação, v. 13, n.27, p. 83-97, jul. dez. 2014. https://doi.org/10.15603/1679-8104/ce.v13n27p83-98

SONTAG, S. Sobre fotografia. São Paulo: Cia das Letras, 2005.

SOUZA, Rosa Fátima. Templos de Civilização - a implantação da Escola Primária graduada no Estado de São Paulo (1890-1910). São Paulo - SP: UNESP, 1998. 300p.

SOUZA, Rosa Fátima. Alicerces da Pátria: história da escola primária no estado de São Paulo (1890 - 1976). Campinas: Mercado de Letras, 2009.

SOUZA, Rosa Fátima; MORAES, Agnes Iara D. O “ensino típico rural”: contribuições para a historiografia da educação rural no Brasil. Documento/Monumento, v. 15, n. 1, set. 2015, p. 277-305. Disponível em: <http://200.129.241.80/ndihr/revista/sub/index2.html >. Acesso em: 21 julho 2017.

WERLE, Flávia Obino Corrêa. Ancorando quadros de formatura na história institucional. In: GT2-História da Educação. 28 $8^{a}$ Reunião Nacional da ANPEd, 2005. Disponível em: <http://www.anped.org.br/sites/default/files/gt02-322-int_ok.pdf〉. Acesso em 10 julho 2017. 